\title{
INTERIM REPORT
}

U.S. Department of Energy

\section{IMPROVED RADIATION DOSIMETRY/RISK ESTIMATES TO FACILITATE ENVIRONMENTAL MANAGEMENT OF PLUTONIUM CONTAMINATED SITES}

\author{
Principal Investigator: Dr. B. R. Scott
}

Institution: Lovelace Respiratory Research Institute

\author{
Collaborators: Dr. Y.-S. Cheng ${ }^{1}$, Dr. M. D. Hoover ${ }^{1}$, Dr. H. Schöllnberger ${ }^{1}$, Dr. Y. Zhou ${ }^{1}$, \\ Mr. G. J. Newton ${ }^{1}$, Dr. R. E. Neft ${ }^{1}$, Dr. M. Ménache ${ }^{1}$, Dr. J. H. Diel ${ }^{1}$ \\ Dr. N. D. Okladnikova ${ }^{2}$, Dr. Z. B. Tokarskaya ${ }^{2}$, Dr. S. V. Osovets ${ }^{3}$, \\ Dr. V. L. Peterson ${ }^{4}$, and Dr. S. S. Yaniv ${ }^{5}$ \\ ${ }^{1}$ Lovelace Respiratory Research Institute (present and past staff), Albuquerque, NM, USA \\ ${ }^{2}$ First Institute of Biophysics, Ozersk, Russia \\ ${ }^{3}$ Ozersk Technological Institute, Ozersk Russia \\ ${ }^{4}$ Rocky Flats Environmental Technology Site, Golden, CO, USA \\ ${ }^{5}$ Retired, Rockville, MD, USA
}

Project Number: 59918

Under Cooperative Agreement Number: DE-FC04-96AL76406

Grant Project Officers: Dr. James Beall, Dr. Gordon Roesler

Project Duration (Initial Project): October 1, 1997 - September 30, 2001*

*One year no-cost extension ends September 30, 2001.

A newly funded, renewed project continues to September 30, 2003 


\section{Table of Contents}

$\underline{\text { Page }}$

Executive Summary.

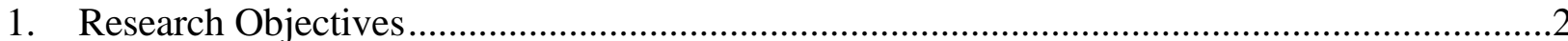

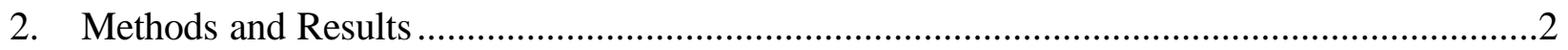

2.1 Methods of Modeling Radioactivity Intake via Inhalation .......................................2

2.2 Particle-Associated Radioactivity Intake Distributions .........................................5

2.3 Less Emphasis on Particle Breakup .................................................................... 12

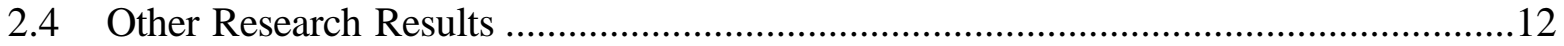

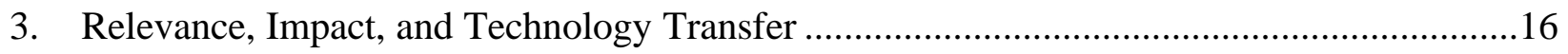

3.1 Recommendations for Setting Radionuclide Soil Action Levels for Rocky Flats ........16

3.2 Implications of our Research for Worker Exposures at Rocky Flats to Pu/Am ...........17

3.3 Implications of our Lung Cancer Risk Assessment Research..................................17

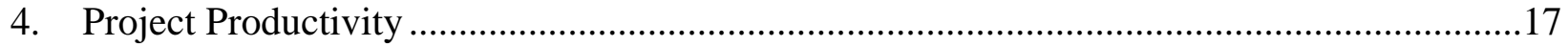

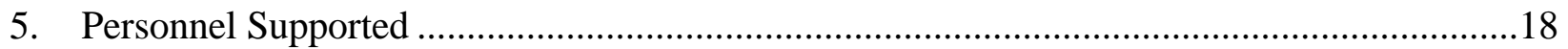

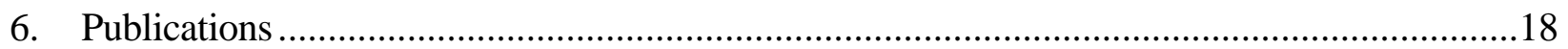

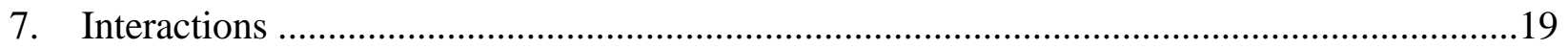

7.1 Presentations (Fully or Partially Supported by this EMSP Project) that Provided for Interactions with Other Researchers: .............................................19

7.2 Web Sites (Fully or Partially Supported by this EMSP Project) Presenting Key Information Related to Our Research: .....................................................................21

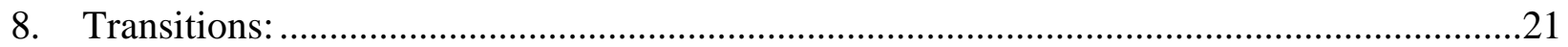

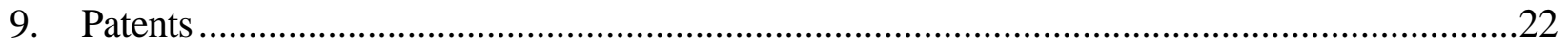

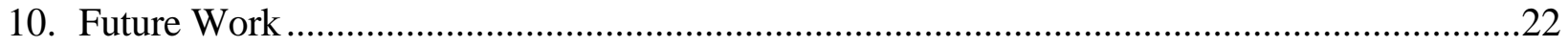

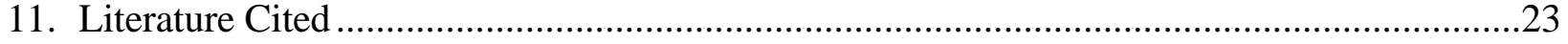




\section{Executive Summary}

This Environmental Management Science Program project has focused on applying basic and applied science methods to improve the following: (1) characterization of plutonium $(\mathrm{Pu})$ /americium(Am) intake by inhalation; (2) subsequent organ radiation doses; and (3) the associated health risks. To achieve this improvement, traditional but inappropriate point estimates have been replaced by more appropriate distributions that relate to uncertainty/ variability. The at-risk populations considered are members of the public who could inhale lowspecific-activity, plutonium dioxide $\left(\mathrm{PuO}_{2}\right)$-contaminated soil arising from Department of Energy (DOE) sites during or after remediation and DOE workers who could inhale pure, highly radioactive $\mathrm{PuO}_{2}$, e.g., related to deactivation and decommissioning (D\&D) accidents or other $\mathrm{Pu}$-related incidents. Our main interest is in the Rocky Flats Environmental Technology Site where cleanup of Pu-contaminated soil and D\&D of Pu-contaminated facilities pose risks to DOE workers and where remediation activities and residual radionuclides in soil after remediation could pose risks to the public. Radionuclides we have focused on are ${ }^{238} \mathrm{Pu},{ }^{239} \mathrm{Pu}$, ${ }^{240} \mathrm{Pu},{ }^{241} \mathrm{Pu},{ }^{242} \mathrm{Pu}$, and the hazardous $\mathrm{Pu}$ daughter radionuclide ${ }^{241} \mathrm{Am}$. For worker exposures during $\mathrm{D} \& \mathrm{D}$ accidents involving $\mathrm{PuO}_{2}$, very small numbers of highly radioactive $\mathrm{PuO}_{2}$ particles could be presented to a worker for inhalation. As was demonstrated in a glovebox-related $\mathrm{PuO}_{2}$ incident that occurred in March 2000 at Los Alamos National Laboratory, take in of radioactivity is stochastic rather than deterministic when relatively small numbers of $\mathrm{PuO}_{2}$ particles are airborne. Exposure scenarios involving relatively small numbers of airborne $\mathrm{PuO}_{2}$ particles represent what we call the stochastic-intake (StI) paradigm. For the StI paradigm, some workers may take in (via inhalation) a relatively large amount of radioactivity, while others may take in little or no radioactivity. Our research has indicated that when very few highly radioactive $\mathrm{PuO}_{2}$ particles are airborne, continuous air monitors (CAMs) may not alarm, while an unlucky worker may take in via inhalation one or two or so highly radioactive particles. In such cases the annual limit on intake could be exceeded (especially for ${ }^{238} \mathrm{PuO}_{2}$ ), and the worker could have $\mathrm{Pu}$ isotopes detected in the urine, but with no knowledge of how it got there, as CAM alarm signaling would not apply. Our research results related to characterizing the stochastic intake of radioactive particles indicate that it would be wise to routinely monitor urine from $\mathrm{Pu}$ workers at Rocky Flats and elsewhere to ensure that unrecognized inhalation intakes of Pu/Am have not occurred while CAMs were silent. We also recommend improvements in controlling worker intakes for the StI paradigm, based on a probabilistic approach described in detail in this report. For considerations of possible public exposure to $\mathrm{Pu}$ residual radioactivity in soil after site remediation, one uses radionuclide soil action levels (RSALs) to provide protection. Associated with exposure scenario-dependent RSALs are cancer risks for the public. These risks are evaluated based on the linear, no-threshold (LNT) model. Thus, based on this model, any amount of radiation (including background radiation) could cause harm. Because of this view, stringent and very costly criteria can be associated with remediation of radionuclidecontaminated sites. Our research has questioned the validity of the LNT model. Preliminary results of our joint Russian Federation/U.S. case-control study of lung cancer induction in Russian nuclear workers by inhaled ${ }^{239} \mathrm{Pu} /{ }^{241} \mathrm{Am}$ in combination with cigarette smoke indicate that cigarette smoking may mask the presence of a radiation dose threshold for lung cancer induction. Further, our research results indicate that previous low-dose risks estimates for lung cancer induction based on the Russian Mayak worker population are likely to be overestimated because of not accounting for the influence of cigarette smoking. 


\section{Research Objectives}

Currently available radiation dosimetry/health-risk models for inhalation exposure to radionuclides are based on deterministic radiation intake and deterministic radiation doses (local and global). These models are not adequate for brief plutonium $(\mathrm{Pu})$ exposure scenarios related to Department of Energy (DOE) decontamination/decommissioning (D\&D) operations because such exposures involve the stochastic-intake (StI) paradigm. For this paradigm, small or moderate numbers of airborne, pure, highly radioactive $\mathrm{PuO}_{2}$ particles could be inhaled and deposited in the respiratory tract in unpredictable numbers (stochastic) during D\&D incidents. Probabilistic relationships govern intake via the respiratory tract for the StI paradigm. An StIparadigm incident occurred on March 16, 2000, at Los Alamos National Laboratory. It involved eight workers who inhaled high-specific-activity, alpha-emitting (HSA- $\alpha \mathrm{E}){ }^{238} \mathrm{PuO}_{2}$ contaminated room air (glovebox-failure incident). Health-risk estimation is not trivial for the StI-exposure paradigm, especially for HSA- $\alpha \mathrm{E}^{238} \mathrm{PuO}_{2}$, as different individuals can have very different and uncertain radioactivity intakes for the same exposure duration and same incident. Indeed, this occurred in the Los Alamos incident. Rather than inappropriate point estimates of intake, dose, and risk, more appropriate probability distributions are needed. A main objective of this project has been to develop a stochastic dosimetry/risk computer model for evaluating radioactivity intake (by inhalation) distributions, organ dose distributions, and health risk distributions for DOE workers who may inhale airborne, alpha-emitting, pure $\mathrm{PuO}_{2}$ at DOE sites such as Rocky Flats. Another objective of this project has been to address the deterministic intake (DI) paradigm where members of the public could inhale, over years, millions and more resuspended, air-transported, $\mathrm{PuO}_{2}$-contaminated dust particles while residing (e.g., farmer) or working (e.g., office worker) at a remediated DOE site that contains mainly residual $\mathrm{PuO}_{2}$ (and daughters) in soil.

\section{Methods and Results}

\subsection{Methods of Modeling Radioactivity Intake via Inhalation}

Inhaling relatively small amounts of $\mathrm{PuO}_{2}$ (and daughters) via resuspended $\mathrm{PuO}_{2}$ contaminated soil could cause lung, liver, and bone cancers in the general population (e.g., citizens who live near Rocky Flats). Inhaling large amounts of $\mathrm{PuO}_{2}$ (and daughters) in the nuclear workplace could lead to radiation deterministic effects such as radiation pneumosclerosis (Okladnikova, 1994b). Thus, for years, environmental and workplace exposure to Pu and associated health risks have been topics of interest to many scientists and clinicians (Altman et al., 1992; CDH, 1990; DOE/EPA/CDPHE, 1996; Gilbert et al., 2000; Hoover and Newton, 1993; Kreisheimer et al., 2000; Koshurnikova et al., 2000; Jones and Zhang, 1994; Krey, 1976; NCRP, 1996, 1999; Newton et al., 1986, 1987; Okladnikova and Burak, 1993; Okladnikova et al., 1992a, b, 1993, 1994a, b; RSALOP 1999a-d; Scott, 1995; Scott et al., 1990, 1993; Tokarskaya and Basogolov, 1995; Tokarskaya and Khokhryakov, 1975; Tokarskaya et al., 1995; US DOE, 1996).

This project has involved the conduct of basic and applied research related to developing improved radiation dosimetry/risk estimates to facilitate environmental management of $\mathrm{Pu}$ contaminated sites. Our research has focused on the DI and StI paradigms: (1) deterministic inhalation intake of $\mathrm{PuO}_{2}$-contaminated, resuspended, dust particles (up to millions of particles); and (2) stochastic inhalation intake of relatively small numbers of LSA- $\alpha E$ (low-specificactivity, alpha-emitting) and $\mathrm{HSA}-\alpha \mathrm{E} \mathrm{PuO}_{2}$ particles by DOE workers involved in D\&D operations. Examples of HSA- $\alpha$ E particles are ${ }^{236} \mathrm{PuO}_{2},{ }^{238} \mathrm{PuO}_{2},{ }^{240} \mathrm{PuO}_{2},{ }^{241} \mathrm{AmO}_{2}$, and

${ }^{242} \mathrm{CmO}_{2}$. Examples of LSA- $\alpha$ E particles are ${ }^{239} \mathrm{PuO}_{2},{ }^{242} \mathrm{PuO}_{2}$, and ${ }^{244} \mathrm{PuO}_{2}$ (Scott et al., 1997). 
For the DI paradigm, every person who inhales the radionuclide-contaminated air takes in radioactivity. There is no issue of whether a person has intake. In contrast, with the StI paradigm, some persons may have intakes, others may not, for the same incident, same duration of exposure, and same location (e.g., same room). Our research has demonstrated that for the StI paradigm, point estimates of radioactivity intake and associated dose are highly unreliable, and instead should be replaced by distributions for possible intakes and doses (Scott et al., 1997; Scott and Fencl, 1999). With the distribution framework, each possible dose will have an associated probability reflecting one's degree of belief in that dose. Thus, our probabilistic characterization is similar in interpretation to Bayesian inference.

We have constructed conditional $\mathrm{PuO}_{2}$ intake (via inhalation) distributions for adults engaged in light work-related exercise, using the convolution method summarized below. The conditional distributions (e.g., see Tables 1 and 2) can be used to construct tables for evaluating unconditional intake distributions (Scott and Fencl, 1999) for persons involved in D\&D accidents. The conditioning relates to the number of particles inhaled. For example, the conditioning could be that exactly $10 \mathrm{PuO}_{2}$ particles are inhaled and deposited in the respiratory tract (or lung or subregion) from airborne $\mathrm{PuO}_{2}$ (with a specified particle size distribution). Table 3 gives information related to means of intake distributions for the adult population considered.

Table 1. Percentile level of the conditional ${ }^{238} \mathrm{PuO}_{2}$ intake distribution associated with fixed amounts of radioactivity intake (Scott and Fencl, 1999) ${ }^{\text {a }}$

\begin{tabular}{|c|c|c|c|c|c|c|c|c|c|c|}
\hline \multirow{3}{*}{$\begin{array}{l}\text { Intake } \\
(\mathrm{Bq})^{\mathrm{b}}\end{array}$} & \multicolumn{10}{|c|}{ Percent Level by Number of Particles Deposited in the Respiratory Tract of Adults ${ }^{\mathrm{a}}$} \\
\hline & \multicolumn{10}{|c|}{ Number of Particles } \\
\hline & 1 & 2 & 3 & 4 & 5 & 6 & 7 & 8 & 9 & 10 \\
\hline 100 & $75.9^{c}$ & $53.1^{\mathrm{d}}$ & 36.5 & 22.3 & 13.5 & 7.49 & 3.98 & 2.08 & 1.08 & 0.54 \\
\hline 200 & 84.4 & 67.6 & 53.5 & 39.2 & 28.9 & 19.4 & 13.3 & 8.60 & 5.77 & 3.76 \\
\hline 300 & 88.2 & 75.0 & 63.3 & 50.6 & 41.1 & 30.3 & 23.1 & 16.4 & 12.4 & 9.08 \\
\hline 400 & 90.6 & 80.0 & 70.3 & 58.8 & 50.2 & 39.7 & 31.4 & 24.3 & 19.3 & 15.4 \\
\hline 500 & 92.4 & 83.2 & 75.0 & 64.9 & 57.0 & 47.1 & 38.8 & 31.4 & 25.9 & 21.4 \\
\hline 600 & 93.6 & 86.0 & 78.9 & 69.6 & 62.7 & 53.0 & 45.7 & 38.0 & 32.1 & 27.0 \\
\hline 700 & 94.6 & 87.8 & 82.0 & 73.5 & 67.0 & 58.5 & 51.3 & 43.6 & 37.7 & 32.0 \\
\hline 800 & 95.3 & 89.3 & 84.0 & 76.7 & 70.4 & 62.6 & 55.9 & 48.8 & 42.8 & 37.1 \\
\hline 900 & 95.9 & 90.7 & 85.8 & 79.5 & 73.9 & 66.5 & 59.8 & 53.0 & 47.4 & 41.8 \\
\hline 1000 & 96.5 & 91.5 & 87.2 & 81.6 & 76.9 & 69.6 & 63.2 & 57.0 & 51.5 & 46.3 \\
\hline
\end{tabular}

${ }^{\mathrm{a}}$ Based on 10,000 trials for each set (column) of percent-level values. Results conditional on $\mathrm{P}(\Omega)=1$. Respiratory tract parameters based on male adults engaged in light, work-related exercise. Multiply column 1 by $\mathrm{S}_{\mathrm{I}} / 280$ to obtain corresponding $\mathrm{Bq}$ for other $\mathrm{PuO}_{2}$ particles.

${ }^{\mathrm{b}}$ Intake amount in Bq.

${ }^{\mathrm{c}}$ This number means that $75.9 \%$ of the intake via single-particle deposition is $\leq 100 \mathrm{~Bq}$.

${ }^{\mathrm{d}}$ This number means that $53.1 \%$ of the intake via two-particle deposition is $\leq 100 \mathrm{~Bq}$. 
Table 2. Percentiles (in $\mathrm{Bq}$ ) for the ${ }^{238} \mathrm{PuO}_{2}$ conditional intake distribution for adults (Scott and Fencl, 1999) ${ }^{\text {a }}$

\begin{tabular}{ccccccccccc}
\hline & \multicolumn{8}{c}{ Percentile (Bq) by Number of Particles Inhaled and Deposited } \\
\cline { 2 - 11 } Level \% & \multicolumn{8}{c}{ Number of Particles } \\
\cline { 2 - 12 } & 1 & 2 & 3 & 4 & 5 & 6 & 7 & 8 & 9 & 10 \\
\hline 2.5 & $0.19^{\mathrm{c}}$ & $2.46^{\mathrm{d}}$ & 8.26 & 19.7 & 32.1 & 53.9 & 79.1 & 108 & 136 & 173 \\
5.0 & 0.43 & 4.47 & 13.5 & 30.1 & 48.4 & 80.3 & 112 & 152 & 187 & 226 \\
50.0 & 18.9 & 86.7 & 174 & 295 & 397 & 547 & 677 & 825 & 961 & 1097 \\
95.0 & 746 & 1532 & 1911 & 2374 & 2588 & 2866 & 3156 & 3454 & 3619 & 3858 \\
97.5 & 1244 & 2239 & 2523 & 2889 & 3150 & 3351 & 3729 & 3993 & 4252 & 4449 \\
Other Statistics: & & & & & & & & & \\
Mean (Bq) & 143 & 306 & 436 & 598 & 718 & 887 & 1040 & 1194 & 1332 & 1473 \\
CV & 2.55 & 1.82 & 1.49 & 1.27 & 1.15 & 1.03 & 0.97 & 0.91 & 0.85 & 0.81 \\
Skewness & 4.62 & 3.19 & 2.69 & 2.27 & 2.07 & 1.80 & 1.81 & 1.65 & 1.49 & 1.38 \\
Kurtosis & 28.2 & 14.6 & 11.4 & 9.55 & 7.93 & 6.60 & 7.23 & 6.23 & 5.53 & 5.14 \\
\hline
\end{tabular}

${ }^{\mathrm{a}}$ Based on 10,000 Monte Carlo trials per data set. Evaluated based on respiratory tract parameters for adult males engaged in light-work related exercise with $\mathrm{P}(\Omega)=1$; CV = coefficient of variability; skewness $=$ coefficient of skewness; kurtosis $=$ coefficient of kurtosis.

${ }^{b}$ Multiply results by $\mathrm{S}_{\mathrm{r}} / 280$ to obtain corresponding results for other $\mathrm{PuO}_{2}$ particles.

${ }^{\mathrm{c}}$ This number means that $2.5 \%$ of the intake from single-particle deposition $\leq 0.19 \mathrm{~Bq}$.

${ }^{\mathrm{d}}$ This number means that $2.5 \%$ of the intake from two-particle deposition $\leq 2.46 \mathrm{~Bq}$.

Table 3. Calculated conditional $\mathrm{PuO}_{2}$ intake means (Bq) for adults as a function of the number of particles inhaled and deposited in the respiratory tract (Scott and Fencl, 1999) ${ }^{\mathrm{a}}$

\begin{tabular}{|c|c|c|c|c|c|c|c|c|c|}
\hline $\begin{array}{l}\text { Particles } \\
\text { Inhaled }^{\text {b }}\end{array}$ & $\begin{array}{c}{ }^{244} \mathrm{PuO}_{2}{ }^{\mathrm{c}} \\
(\mathrm{Bq})\end{array}$ & $\begin{array}{c}{ }^{242} \mathrm{PuO}_{2} \\
(\mathrm{~Bq})\end{array}$ & $\begin{array}{c}{ }^{239} \mathrm{PuO}_{2} \\
(\mathrm{~Bq})\end{array}$ & $\begin{array}{c}{ }^{240} \mathrm{PuO}_{2} \\
(\mathrm{~Bq})\end{array}$ & $\begin{array}{c}{ }^{238} \mathrm{PuO}_{2} \\
\text { (Bq) }\end{array}$ & $\begin{array}{c}{ }^{236} \mathrm{PuO}_{2}{ }^{\mathrm{c}} \\
(\mathrm{Bq})\end{array}$ & $\mathrm{CV}^{\mathrm{d}}$ & Skewness $^{\mathrm{d}}$ & Kurtosis ${ }^{\mathrm{d}}$ \\
\hline 1 & 0.00015 & 0.0327 & 0.511 & 1.89 & 143 & 4341 & 2.55 & 4.62 & 28.2 \\
\hline 2 & 0.00032 & 0.0699 & 1.09 & 4.04 & 306 & 9289 & 1.82 & 3.19 & 14.6 \\
\hline 3 & 0.00045 & 0.1 & 1.56 & 5.76 & 436 & 13236 & 1.49 & 2.69 & 11.4 \\
\hline 4 & 0.00062 & 0.136 & 2.13 & 7.89 & 597 & 18123 & 1.27 & 2.27 & 9.55 \\
\hline 5 & 0.00074 & 0.164 & 2.56 & 9.49 & 718 & 21796 & 1.15 & 2.07 & 7.93 \\
\hline 6 & 0.00092 & 0.203 & 3.17 & 11.7 & 887 & 26927 & 1.03 & 1.80 & 6.60 \\
\hline 7 & 0.00108 & 0.238 & 3.71 & 13.74 & 1040 & 31571 & 0.97 & 1.81 & 7.23 \\
\hline 8 & 0.00124 & 0.273 & 4.26 & 15.78 & 1194 & 36246 & 0.91 & 1.65 & 6.23 \\
\hline 9 & 0.00138 & 0.304 & 4.76 & 17.6 & 1332 & 40436 & 0.85 & 1.49 & 5.53 \\
\hline 10 & 0.00153 & 0.337 & 5.261 & 19.5 & 1473 & 44719 & 0.81 & 1.38 & 5.14 \\
\hline
\end{tabular}

${ }^{\mathrm{a}}$ Respiratory tract parameters based on results of adult males engaged in light exercise were obtained by multiplying results obtained for ${ }^{238} \mathrm{PuO}_{2}$ by $\mathrm{S}_{\mathrm{I}} / 280$. Results are conditional on $\mathrm{P}(\Omega)=1$.

${ }^{\mathrm{b}}$ Particles inhaled and deposited in the respiratory tract.

${ }^{\mathrm{c}}$ Not reported as being present at Rocky Flats but included for completeness.

${ }^{\mathrm{d}} \mathrm{CV}=$ coefficient of variability; skewness = coefficient of skewness; kurtosis = coefficient of kurtosis. 


\subsection{Particle-Associated Radioactivity Intake Distributions}

\subsubsection{Single-Particle Associated Radioactivity Intake Distributions}

Here we summarize our work on characterizing single-particle associated, radioactivity intake distributions. The distributions help to evaluate radioactivity intake via inhaling multiple particles during D\&D accidents or incidents such as occurred at Los Alamos on March 16, 2000, where a glovebox failed, releasing ${ }^{238} \mathrm{PuO}_{2}$ to room air inhaled by eight workers. Scientists at our Institute are participating in characterizing the source term for the Los Alamos incident. The data to be developed will be used in our project.

We indicated the single-particle-associated radioactivity intake distribution as $f_{l}(A)$, where $A$ is the radioactivity intake associated with the single particle deposited in the respiratory tract (or a specific region or subregion) via inhalation. The subscript 1 indicates that the distribution applies to a single particle. The distribution $f_{l}(A)$ depends on the region of the respiratory tract, the age of the individual, the level of physical activity, and the particle size distribution $\Phi(d)$, where $d$ is the aerodynamic diameter.

The product $f_{l}(A) d A$ gives the fraction of single-particle associated radioactivity intakes (via single particles) with radioactivity in the very small interval $(A, A+d A)$. The distribution $f_{l}(A)$ does not depend on particle presentation, $\Omega$ but accounts for particle inhalability, $P_{I}(d)$, and particle deposition probability, $P_{D e p}(d)$ (Scott et al., 1997). In addition, both $P_{I}(d)$ and $P_{D e p}(d)$ depend on particle density, size, and shape.

The presentation, $\Omega$ is the mean number of particles presented to a human receptor for inhalation over the period of interest, assuming we are dealing with the StI paradigm. The number of particles presented for inhalation is assumed to have a Poisson distribution. We have used the notation $P(n \mid \Omega)$ to indicate the Poisson probability that exactly $\mathrm{n}$ airborne particles of interest are presented to an individual for inhalation during the period of interest. $P(n \mid \Omega)$ is useful for conducting evaluations over many inhalations (breaths) and is related to the particle availability, $P_{A}(d)$, which is associated with a single breath (Scott et al., 1997).

The particle availability, $P_{A}(d)$, represents the probability that a particle of interest will be contained in a tidal volume of air just before inhaling (Scott et al., 1997). Calculated availability of monodisperse, $\mathrm{LSA}-\alpha \mathrm{E}$, and $\mathrm{HSA}-\alpha \mathrm{E} \mathrm{PuO}$ aerosols is presented in Figure 1 as a function of particle equivalent-volume diameter, $d_{e v}$, when the air radioactivity concentration is 1 DAC (derived air concentration) (Scott et al., 1997). Calculations were based on a 1.3-L tidal volume and a particle density of $10 \mathrm{~g} / \mathrm{cm}^{3}$ (Kotrappa et al., 1972; Raabe, 1994) and ICRP Publication 30 DACs (ICRP, 1979).

The equivalent volume diameter, $d_{e v}$, is the diameter of a sphere with the same density and mass as the particle of interest. Use of equivalent volume diameter facilitates evaluating particle radioactivity for irregularly shaped particles. We calculate equivalent volume diameter using mathematical equations presented in ICRP Publication 66 (ICRP, 1994).

For the stochastic-intake paradigm, where at most relatively small numbers of airborne particles are inhaled, the particle presentation $\Omega$ and associated Poisson probability, $\mathrm{P}(\mathrm{n} \mid \Omega)$, are important in characterizing the variability of the unconditional intake or radioactivity (Scott and Fencl, 1999). Here unconditional intake means that there is no focus on a fixed number of particles being inhaled. 


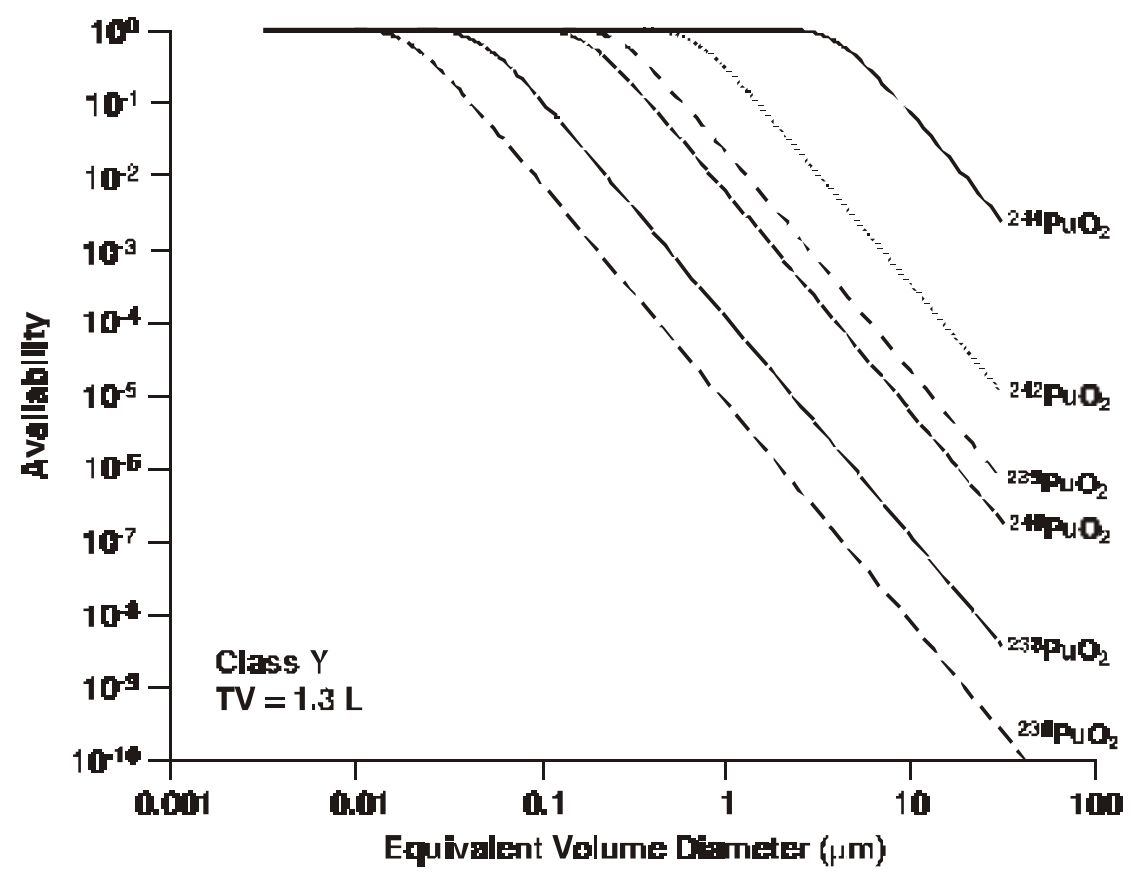

Figure 1. Availability $\mathrm{PA}(\mathrm{d})$ of airborne, monodisperse, $\mathrm{PuO}_{2}$ particles evaluated at the derived air concentration (Scott et al., 1997).

\subsubsection{Convolution Method for Multiple Particle Intakes}

The radioactivity intake distribution for inhaling two particles of interest, sampled by inhalation from an airborne particle-size distribution, $\Phi(d)$, is given by $f_{2}(A)$ where

$$
f_{2}(A)=\int_{0}^{A} f_{1}(x) f_{1}(A-x) d x .
$$

The radioactivity intake distribution for inhaling three particles of interest, sampled from a given particle size distribution, $\Phi(d)$, is given by $f_{3}(A)$, where

$$
f_{3}(A)=\int_{0}^{A} f_{1}(x) f_{2}(A-x) d x .
$$

Similarly, for $n+1$ particles the radioactivity intake distribution is given by

$$
f_{n+1}(A)=\int_{0}^{A} f_{1}(x) f_{n}(A-x) d x .
$$

We were not able to develop an analytical solution for $f_{l}(A)$. However, an empirical distribution was developed based on particle-size-dependent deposition efficiencies (adjusted for inhalability) associated with the ICRP 66 respiratory tract dosimetry model (ICRP, 1994). The convolutions for multiple-particle intake were carried out via the standard Monte Carlo method using Crystal Ball software (Decisioneering, 1996). For multiple-particle intake, separate singleparticle, empirical distributions were used. For example, for a two-particle intake, empirical distributions called $\underline{O n e}$ and $\underline{T w o}$ were used. A particle was sampled from distribution One and its radioactivity calculated via a macro that accounted for particle shape, mass, etc., and converted $d$ to the equivalent volume diameter $d_{e v}$. A second particle was sampled from 
distribution Two and its radioactivity calculated. Then, both particle radioactivities were added, and the sum was stored. This procedure was repeated 10,000 times with Crystal Ball Monte Carlo. The software runs inside of Excel, which facilitates using Excel macros. This approach yields an empirical intake distribution that varies solely because of sampling, via inhalation, from a distribution $\Phi(d)$.

Figures 2-5 show calculated distributions $f_{1}(A), f_{5}(A), f_{10}(A)$, and $f_{30}(A)$ for intake by adults involved in a $\mathrm{D} \& \mathrm{D}$ accident involving brief loss of respirator protection and brief inhalation exposure to ${ }^{238} \mathrm{PuO}_{2}$.

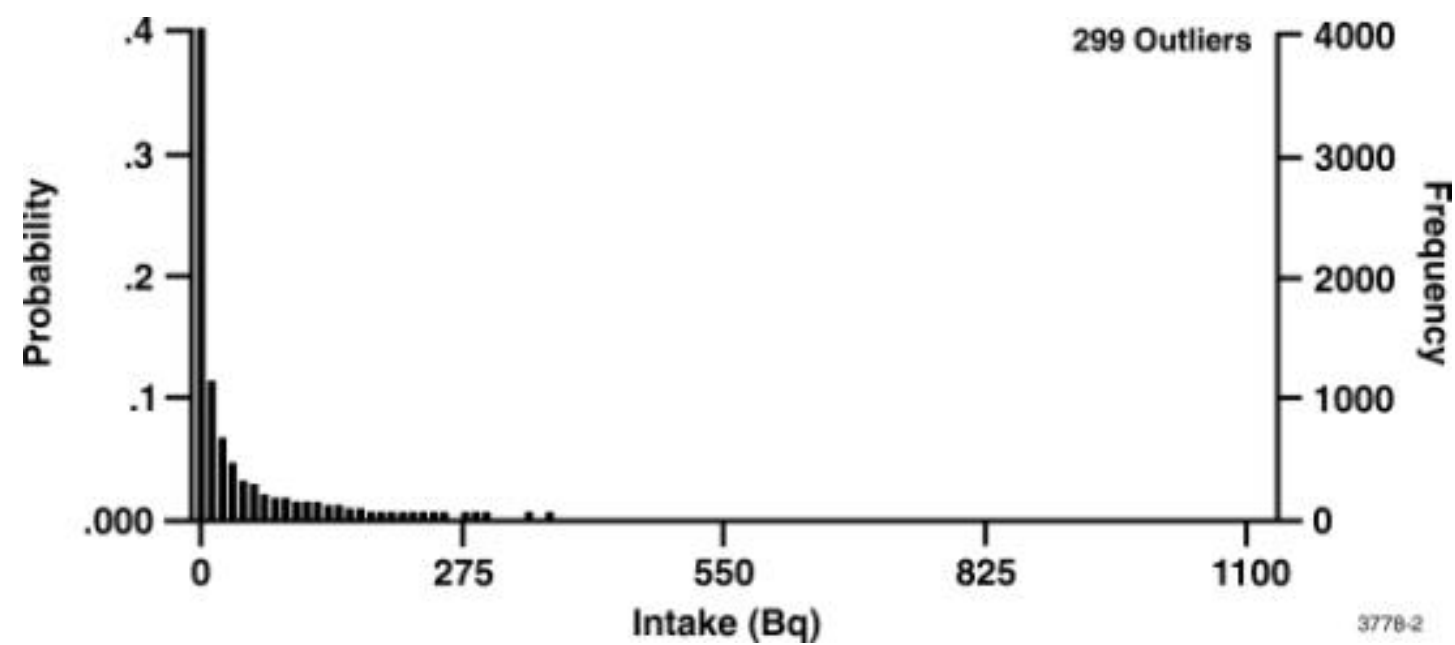

Figure 2. Conditional radioactivity-intake distribution, $f_{l}(A)$, for a single ${ }^{238} \mathrm{PuO}_{2}$ particle intake by adults engaged in light work-related exercise (Scott and Fencl, 1999). The distribution was evaluated numerically based on 10,000 Monte Carlo trials, a polydisperse size distribution with an activity median aerodynamic diameter of $5 \mu \mathrm{m}$, and a geometric standard deviation of 2.5.

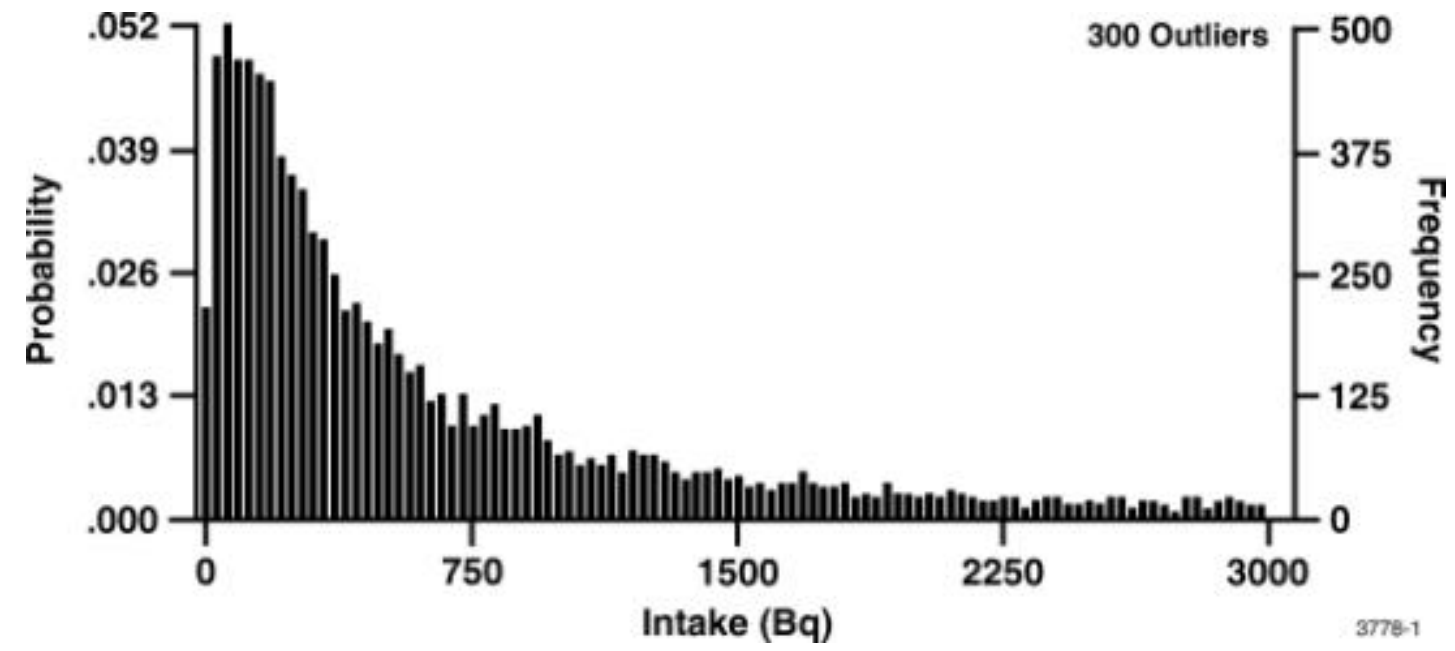

Figure 3. Conditional radioactivity-intake distribution, $f_{5}(A)$, for a five ${ }^{238} \mathrm{PuO}_{2}$ particle intake by adults engaged in light work-related exercise (Scott and Fencl, 1999). The distribution was evaluated numerically based on 10,000 Monte Carlo trials, a polydisperse size distribution with an activity median aerodynamic diameter of $5 \mu \mathrm{m}$, and a geometric standard deviation of 2.5. 


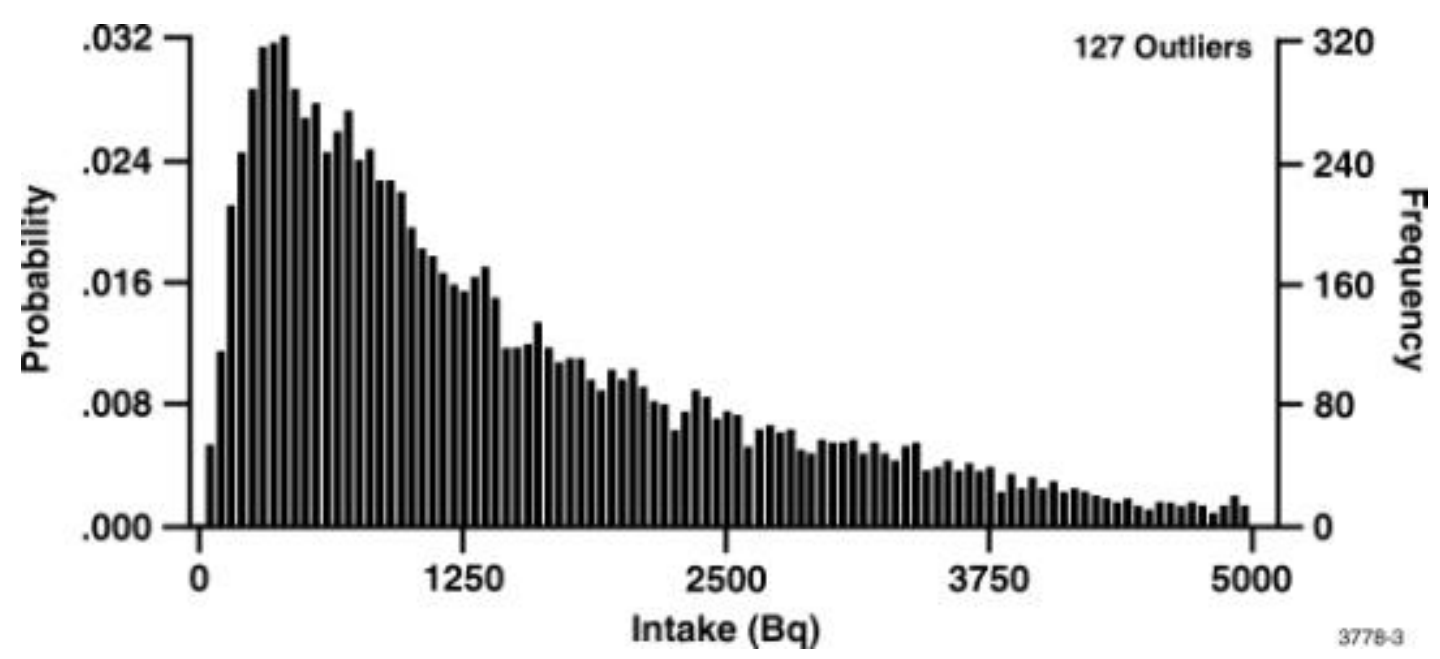

Figure 4. Conditional radioactivity-intake distribution, $f_{10}(A)$, for a $10{ }^{238} \mathrm{PuO}_{2}$ particle intake by adults engaged in light work-related exercise (Scott and Fencl, 1999). The distribution was evaluated numerically based on 10,000 Monte Carlo trials, a polydisperse size distribution with an activity median aerodynamic diameter of $5 \mu \mathrm{m}$, and a geometric standard deviation of 2.5.

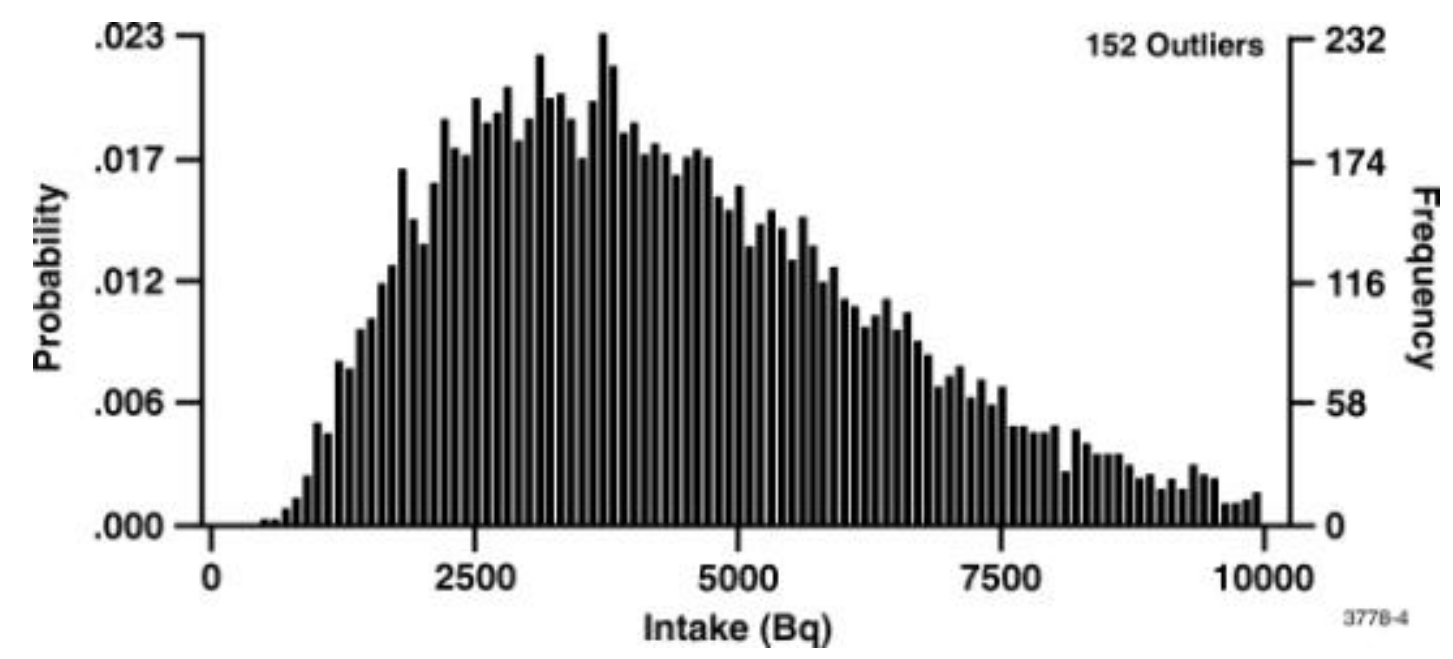

Figure 5. Conditional radioactivity-intake distribution, $f_{30}(A)$, for a $30{ }^{238} \mathrm{PuO}_{2}$ particle intake by adults engaged in light work-related exercise (Scott and Fencl, 1999). The distribution was evaluated numerically based on 10,000 Monte Carlo trials, a polydisperse size distribution with an activity median aerodynamic diameter of $5 \mu \mathrm{m}$, and a geometric standard deviation of 2.5 .

\subsubsection{Method of Scaling for Different Pu Isotopes}

Each possible value for the possible intake of radioactivity has an associated probability reflecting degree of belief in the value. Male and female differences were judged as negligible so that calculations based on respiratory tract parameters for adult males are presumed to apply (to a first approximation) to adult females. Evaluations are based on a polydisperse size distribution with an activity median aerodynamic diameter of $5 \mu \mathrm{m}$ and a geometric standard deviation of 2.5, as recommended in ICRP Publication 66 (ICRP, 1994) for nuclear workers. The results clearly indicate that considerable variability in intake by nuclear workers would be expected when small numbers of the HSA- $\alpha E^{238} \mathrm{PuO}_{2}$ particles are inhaled. Here, the variability 
in intake is solely related to particle polydispersity (i.e., varying sizes). The distribution for

${ }^{238} \mathrm{PuO}_{2}$ can easily be scaled to ${ }^{239} \mathrm{PuO}_{2},{ }^{240} \mathrm{PuO}_{2}$, or ${ }^{242} \mathrm{PuO}_{2}$, based on particle relative specific activity $S_{r}$ (Table 4). The relative specific activity has been evaluated relative to ${ }^{239} \mathrm{PuO}_{2}$.

Particle radioactivity $A$ (in $B q$ ) is evaluated using (Scott et. al., 1997)

$$
A \text { in } B q=\rho S_{r} d_{e v}{ }^{3} / 845 \text {. }
$$

The parameter, $\rho$, is the particle density in $\mathrm{g} / \mathrm{cm}^{3}$, and $d_{e v}$ again is the equivalent volume diameter.

Table 4. Relative specific activities for $\mathrm{PuO}_{2}$ aerosols (Scott et al., 1997)

\begin{tabular}{ccc}
\hline Type of Particle & Specific Activity Class ${ }^{\mathrm{a}}$ & $\begin{array}{c}\text { Relative Specific Activity } \mathrm{S}_{\mathrm{r}} \\
\text { (dimensionless) }\end{array}$ \\
\hline${ }^{242} \mathrm{PuO}_{2}$ & LSA- $\alpha \mathrm{E}$ & $8.3 \times 10^{-2}$ \\
${ }^{239} \mathrm{PuO}_{2}$ & LSA- $\alpha \mathrm{E}$ & $1.0^{\mathrm{b}}$ \\
${ }^{240} \mathrm{PuO}_{2}$ & HSA- $\alpha \mathrm{E}$ & 3.7 \\
${ }^{238} \mathrm{PuO}_{2}$ & HSA- $\alpha \mathrm{E}$ & $2.8 \times 10^{2}$ \\
\hline
\end{tabular}

${ }^{\mathrm{a}} \mathrm{LSA}-\alpha \mathrm{E}=$ low-specific -activity, alpha-emitting source; HSA- $\alpha \mathrm{E}=$ highspecific-activity, alpha-emitting source.

${ }^{\mathrm{b}}$ Corresponding absolute specific activity $=2.26 \times 10^{3} \mathrm{MB} / \mathrm{g}$.

\subsubsection{Using Conditional Intake Distributions}

The conditional distributions can be used to evaluate probabilities for exceeding, via inhalation, the intake of a specified amount of radioactivity (e.g., Annual Limit on Intake [ALI]). One of our recent publications (Scott and Fencl, 1999) shows how to carry out the necessary calculations as well as how to address mixtures of different alpha-emitting plutonium isotopes.

\subsubsection{Deterministic Intake Paradigm: Inhaling $\mathrm{PuO}_{2}$ in Resuspended Dust}

We have conducted similar evaluations for inhalation exposure of members of the public to $\mathrm{PuO}_{2}$-contaminated soil. However, because of dilution of the radioactivity by the soil, the specific activity of the contaminated soil is much lower than for pure $\mathrm{PuO}_{2}$. Thus, for inhaling the same amount of radioactivity as for inhaling pure $\mathrm{PuO}_{2}$, large numbers of contaminated dust particles need to be inhaled. We were interested in starting from the stochastic intake paradigm and systematically increasing the number of particles inhaled until we crossed the boundary between the StI and DI paradigms.

Thus, for $\mathrm{PuO}_{2}$-contaminated soil, we evaluated conditional radioactivity intake distributions. We started from a single dust particle and by convolution generated conditional intake distributions for up to 5 million dust particles. Again, the numerical convolution approach was used. For Pu-contaminated soil, we used a density of $2 \mathrm{~g} / \mathrm{cm}^{3}$ and a reference specific activity of $1 \mathrm{~Bq} / \mathrm{g}(27 \mathrm{pCi} / \mathrm{g})$ for generic $\mathrm{PuO}_{2}$-contaminated dust particles. With this approach, results can be scaled to any $\mathrm{Pu}$ isotope of interest of any mixture of $\mathrm{Pu}$ isotopes in soil. Note that the density is considerably less than the $10 \mathrm{~g} / \mathrm{cm}^{3}$ density used for pure $\mathrm{PuO}_{2}$. Evaluations were carried out for adults engaged in light exercise based on respiratory tract parameters for males as 
was done for pure $\mathrm{PuO}_{2}$. Thus, again we have neglected what we expect to be small differences between males and females.

Results for $100,1000,10,000,100,000$, or 1,000,000 dust particles are presented in Figures 6-10.

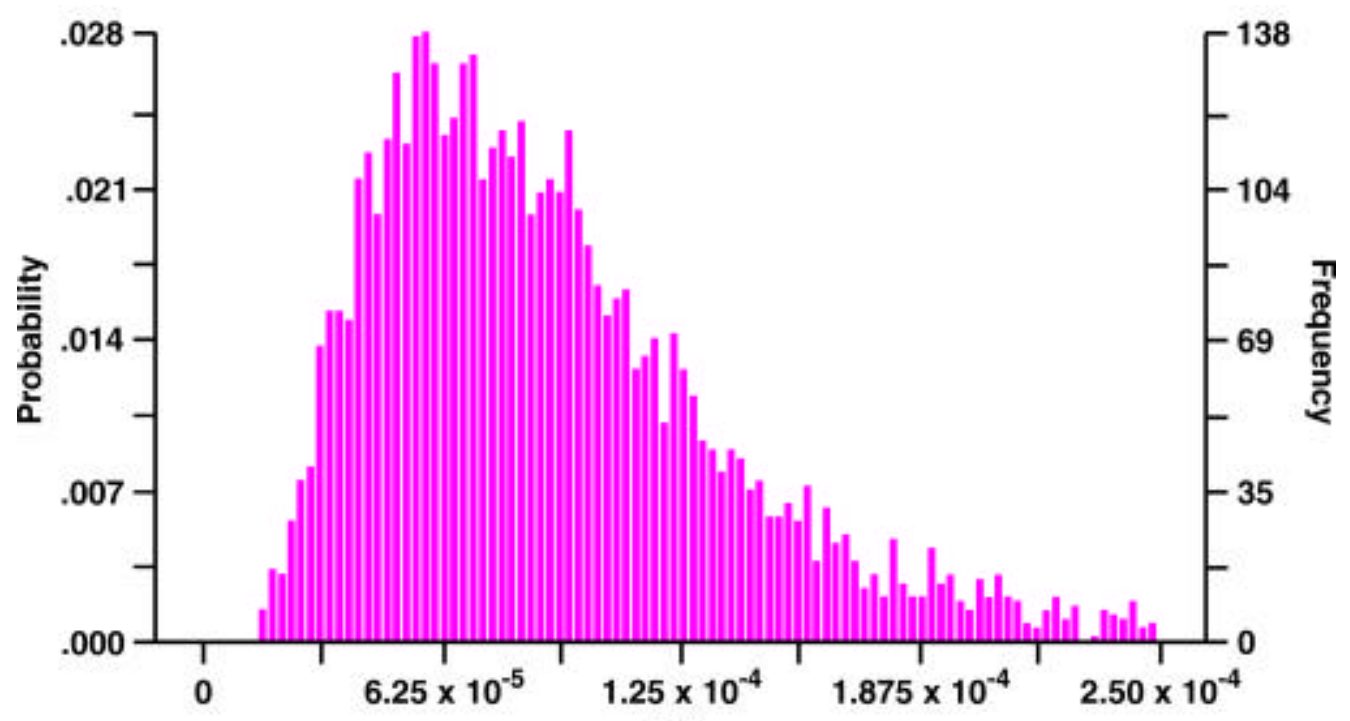

fCi

Figure 6. Conditional radioactivity-intake distribution, $f_{100}(A)$, for a $100 \mathrm{PuO}_{2}$-contaminated dust-particle intake by adults (Scott et al., 1999) when the contaminated dust has a specific activity of $1 \mathrm{~Bq} / \mathrm{g}$. The distribution was evaluated numerically based on 10,000 Monte Carlo trials, a polydisperse size distribution, an activity median aerodynamic diameter of $1 \mu \mathrm{m}$, and a geometric standard deviation of 2.5.

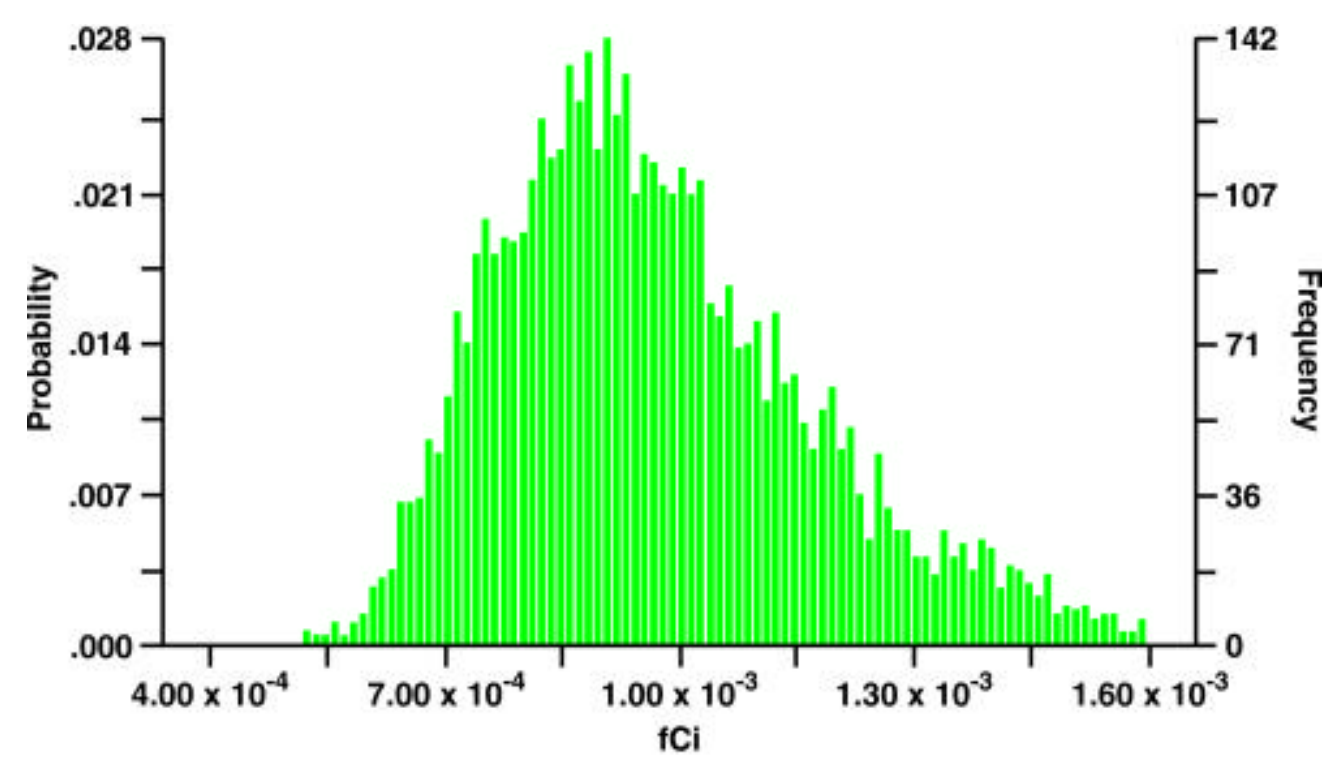

Figure 7. Conditional radioactivity-intake distribution, $f_{1,000}(A)$, for a 1,000 $\mathrm{PuO}_{2}$-contaminated, dust-particle intake by adults (Scott et al., 1999) when the contaminated dust has a specific activity of $1 \mathrm{~Bq} / \mathrm{g}$. The distribution was evaluated numerically based on 10,000 Monte Carlo trials, a polydisperse size distribution with an activity median aerodynamic diameter of $1 \mu \mathrm{m}$, and a geometric standard deviation of 2.5 . 


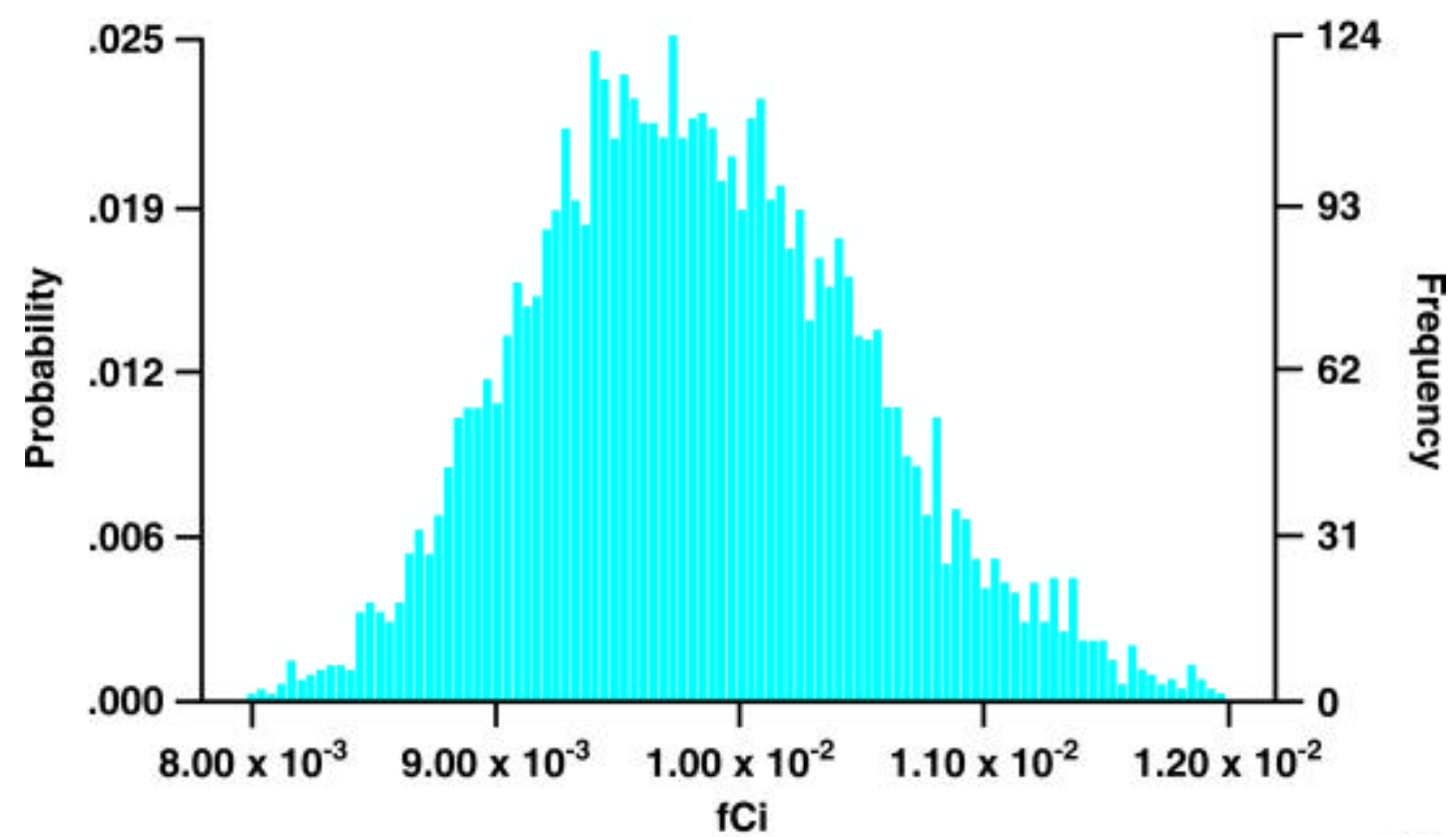

Figure 8. Conditional radioactivity-intake distribution, $f_{10,000}(A)$, for a $10,000 \mathrm{PuO}_{2}$-contaminated, dust-particle intake by adults (Scott et al., 1999) when the contaminated dust has a specific activity of $1 \mathrm{~Bq} / \mathrm{g}$. The distribution was evaluated numerically based on 10,000 Monte Carlo trials, a polydisperse size distribution with an activity median aerodynamic diameter of $1 \mu \mathrm{m}$, and a geometric standard deviation of 2.5 .

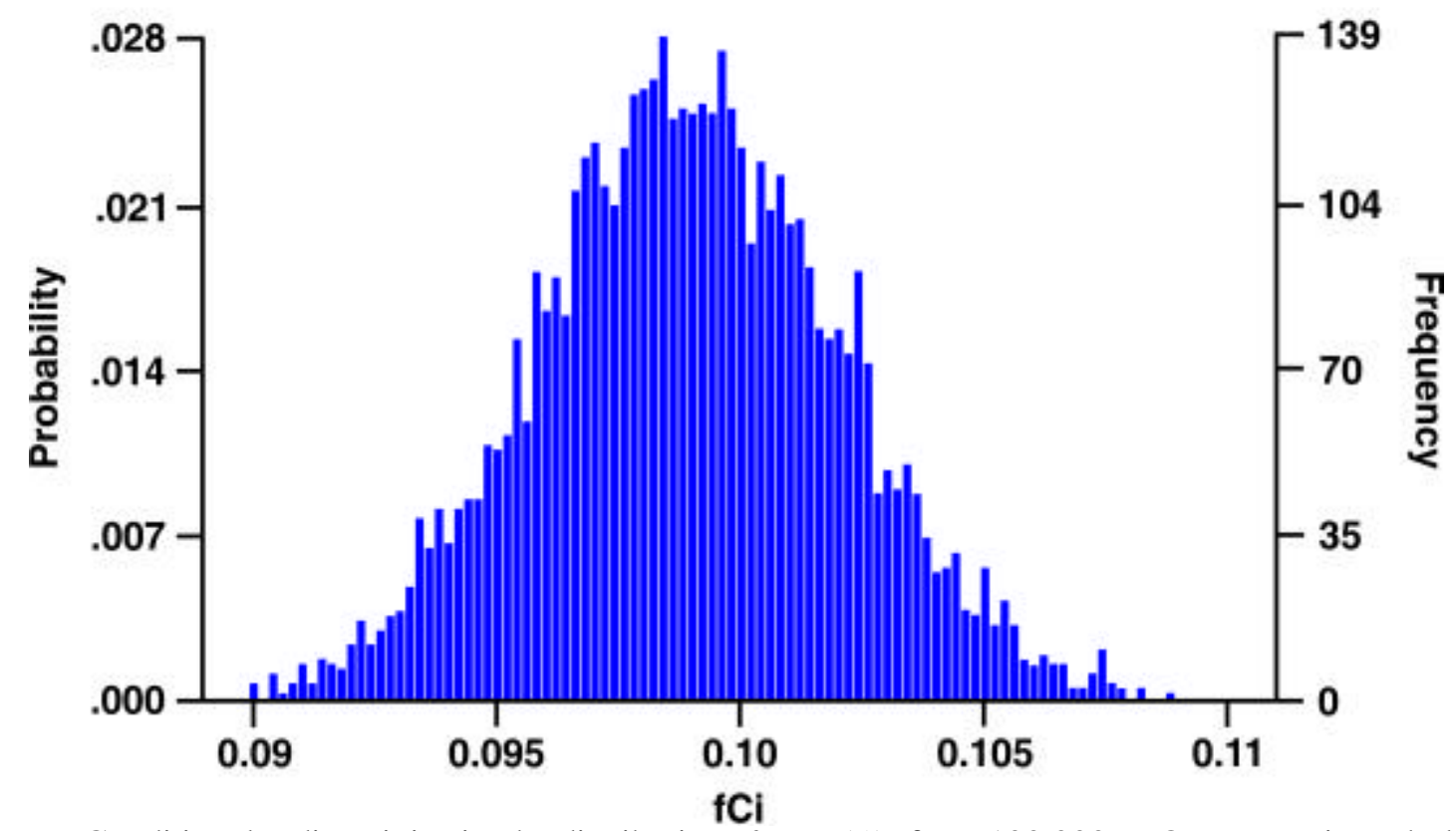

Figure 9. Conditional radioactivity-intake distribution, $f_{100,000}(A)$, for a $100,000 \mathrm{PuO}_{2}$-contaminated, dustparticle intake by adults (Scott et al., 1999) when the contaminated dust has a specific activity of $1 \mathrm{~Bq} / \mathrm{g}$. The distribution was evaluated numerically based on 10,000 Monte Carlo trials, a polydisperse size distribution with an activity median aerodynamic diameter of $1 \mu \mathrm{m}$, and a geometric standard deviation of 2.5 . 


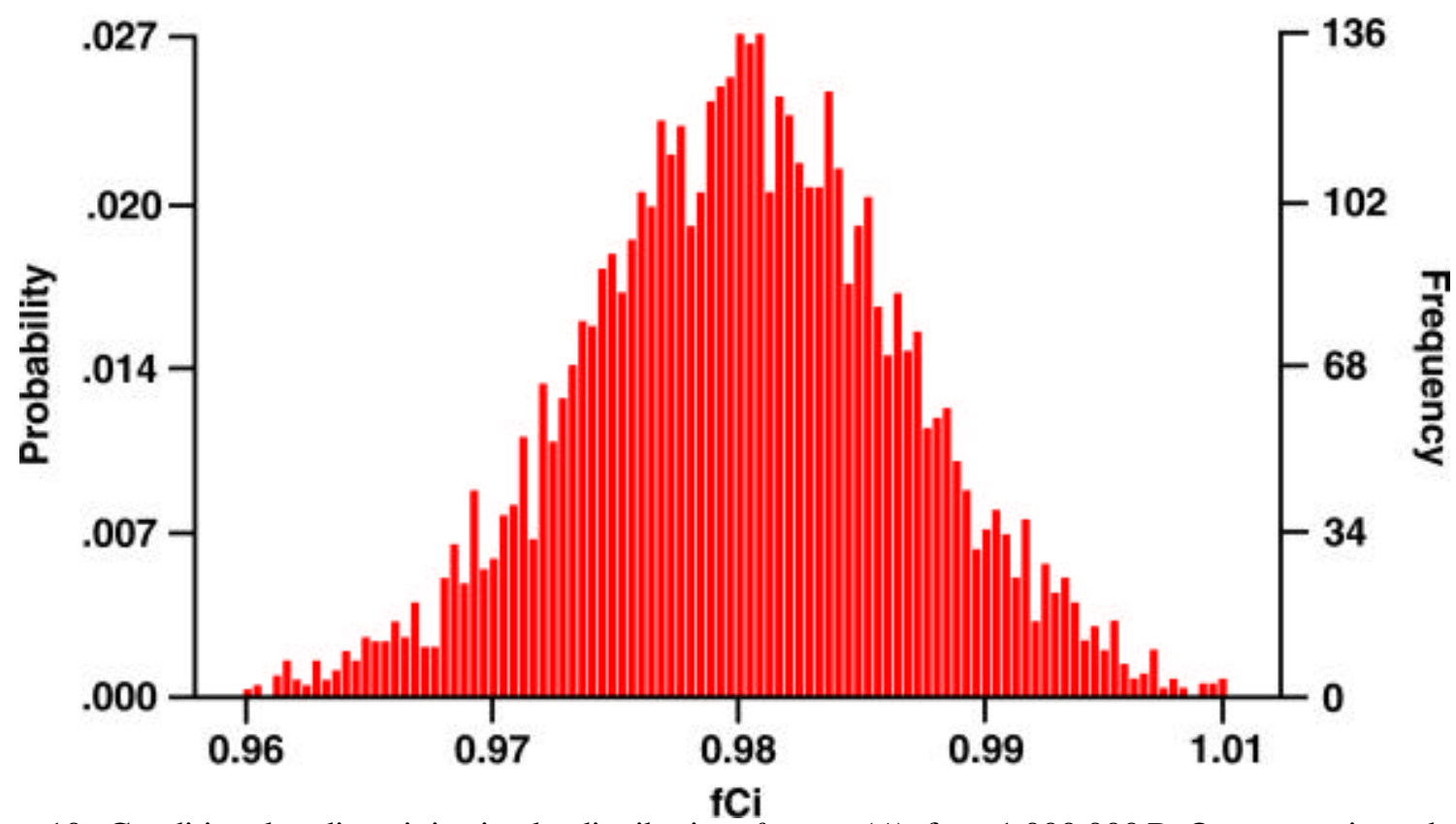

Figure 10. Conditional, radioactivity-intake distribution, $f_{1,000,000}(A)$, for a $1,000,000 \mathrm{PuO}_{2}$-contaminated, dustparticle intake by adults (Scott et al., 1999) when the contaminated dust has a specific activity of $1 \mathrm{~Bq} / \mathrm{g}$. The distribution was evaluated numerically based on 10,000 Monte Carlo trials, a polydisperse size distribution with an activity median aerodynamic diameter of $1 \mu \mathrm{m}$, and a geometric standard deviation of 2.5 .

The 1,000,000 particle intake distribution is clearly in the deterministic paradigm as the variability in intake related to particle polydispersity (varying sizes) has almost vanished. Based on this research, specific recommendations were made related to developing final radionuclide soil action levels (RSALs) for the Rocky Flats site that were placed on our Pu web site (www.radiation-scott.org) and presented at the $218^{\text {th }}$ American Chemical Society National Meeting \& Exposition, New Orleans, LA, August 22-26, 1999 (Scott et al., 1999). The recommendations are presented in Section 3.1.

\subsection{Less Emphasis on Particle Breakup}

Based on early work at LRRI, we have a good understanding of the importance of particle breakup for inhaled ${ }^{238} \mathrm{PuO}_{2}$ (Diel and Mewhinney, 1983; Mewhinney and Diel, 1983; Hickman et al., 1995). The breakup arises from alpha decay energy deposited in the ${ }^{238} \mathrm{PuO}_{2}$ matrix. The breakup increases the rate of translocation of radioactivity from the respiratory tract to liver and bone. However, this appears to be mainly important for ${ }^{238} \mathrm{PuO}_{2}$ and not so important for ${ }^{239} \mathrm{PuO}_{2}$, ${ }^{240} \mathrm{PuO}_{2},{ }^{241} \mathrm{PuO}_{2}$ (low-energy beta source), or ${ }^{242} \mathrm{PuO}_{2}$. All of the exposure scenarios we have dealt with so far have involved only a very small amount of ${ }^{238} \mathrm{PuO}_{2}$ so that particle breakup has not been an issue. However, regarding the ${ }^{238} \mathrm{Pu}$ incident that recently occurred at Los Alamos where eight individuals inhaled ${ }^{238} \mathrm{Pu}$-contaminated air, particle breakup may contribute to an increase in the bone and liver cancer risks beyond what would be expected without the breakup.

\subsection{Other Research Results}

\subsubsection{Some Useful Results Related to Microdosimetry}

This project has partially supported modeling research related to developing a biological microdosimetry system based on quantal radiation effects data. Assuming biological variability 
in cell survival data to arise mainly from variability in the microdose to the critical genomic target, and assuming a binomial distribution of the number of cells that survive a given macroscopic dose, we have introduced a new approach to biological microdosimetry (Scott and Schöllnberger, 2000). This approach uses standard Monte Carlo methods so far. Figure 11 shows the empirical microdose distribution generated for a 0.5 Gy mean (measured) alpha radiation dose (absorbed dose) to $\mathrm{C} 3 \mathrm{H}$ 10T1/2 cells, based on the calibration curve presented in Figure 12 (Scott and Schöllnberger, 2000). The notation $\mathrm{E}\{\mathrm{z}\}$ in Figure 11 indicates the mean of the microdose distribution. The genomic damage hazard in Figure 12 was obtained by taking the natural $\log$ of the surviving fraction and multiplying the results by -1 .

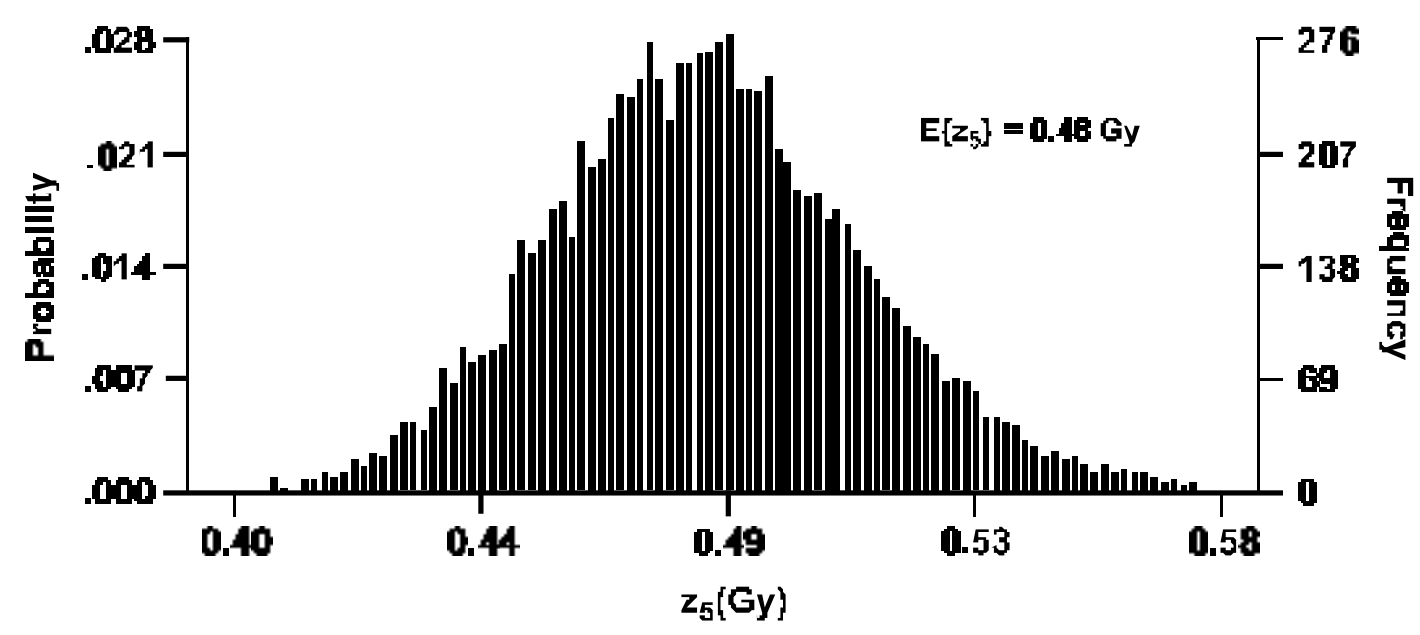

Figure 11. Simulated microdose distribution to the critical biological target when C3H 10T1/2 cells are killed by exposure to a macroscopic alpha radiation dose $D_{5}=0.5 \mathrm{~Gy}$. Results are based on biological microdosimetry as applied to cell survival data of Bettega et al. $(1990,1992)$.

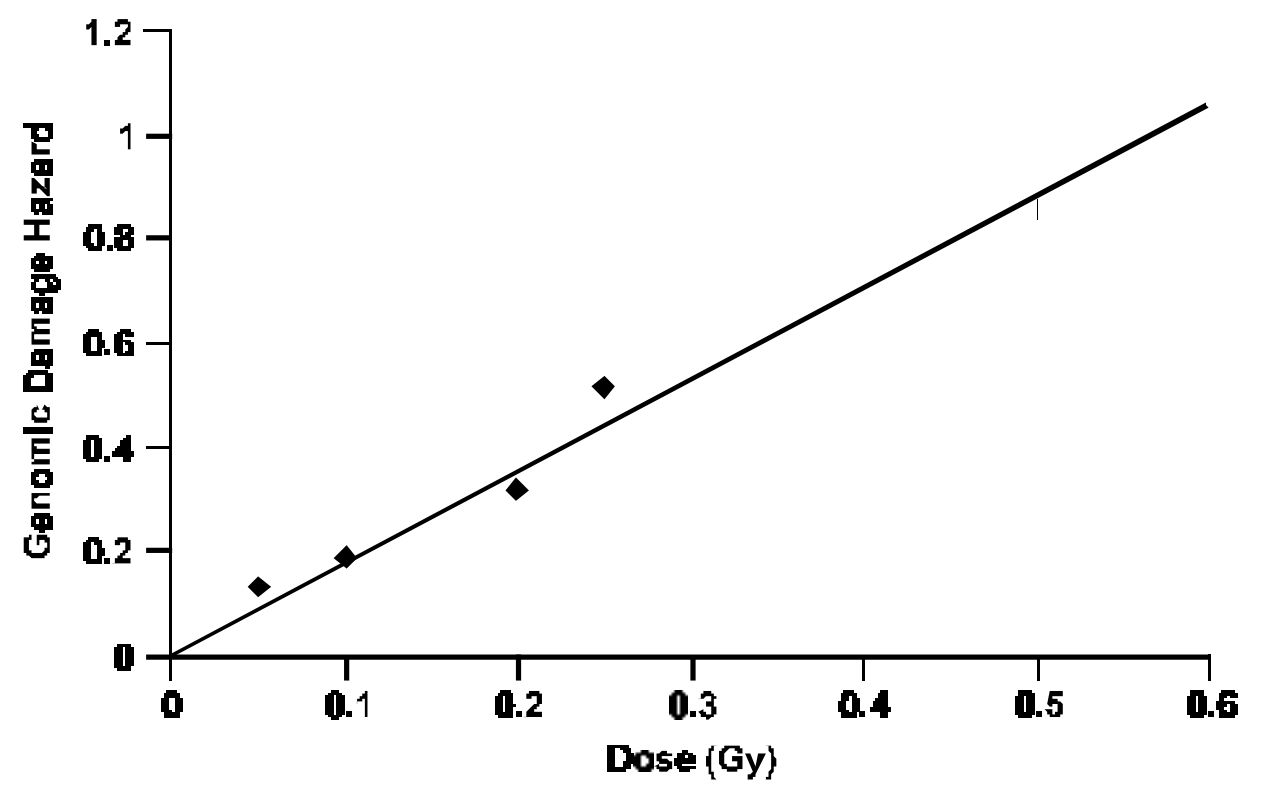

Figure 12. Application of the linear, no-threshold model to dose-response data for the genomic damage hazard for killing $\mathrm{C} 3 \mathrm{H} 10 \mathrm{~T} 1 / 2$ cells by alpha irradiation. The genomic damage hazard data are based on cell survival data reported by Bettega et al. $(1990,1992)$. The slope of the line is $1.747 \pm 0.08 \mathrm{~Gy}^{-1}$. The correlation coefficient $\left(\mathrm{R}^{2}\right)$ is 0.972 . 
Our current results for low alpha radiation doses indicate that the empirical microdose distributions generated are adequately characterized by both the lognormal and gamma distributions for the in vitro exposures considered. These judgements were based on three statistical tests for goodness of fit: Chi-square, Anderson-Darling, and Kolmolgorov-Smirnov tests. The cited reference (Scott and Schöllnberger, 2000) is a submitted manuscript. We feel strongly that we can improve on the microdose distribution generated by using Bayesian inference implemented via Markov Chain Monte Carlo (MCMC; Carlin and Louis, 1996; Gamerman, 1997; Gilks et al., 1997; Miller and Inkret, 1996a, b). Distributions generated with our current forward Monte Carlo method could be used as priors in the MCMC analyses along with quantal biological data of interest (e.g., cell survival data). Posterior distributions generated would then be used for the final microdose distributions (e.g., to the genome).

\subsubsection{Results Related to Alpha-radiation Induced Cancer}

Research in our Environmental Science Management Project (EMSP) project has benefited from other research at our Institute that focused on understanding the sequence of events in genotoxicant-induced carcinogenesis. The development of cancer can involve multiple steps and appears to be related to the evolution in a stochastic manner of dysfunctional genes that possess genomic instability induced by genotoxic agents such as ionizing radiation. The majority of these dysfunctional genes act by subverting the control of cell proliferation (Lechner and Mauderly, 1994).

Age-adjusted human lung cancer incidence data suggest that lung cancer results from three to six (or perhaps more) genomic derangements that accumulate over many years in progeny of cells initiated by exposure to agents such as radiation. These derangements are molecular biological markers for genomic instability. As individual steps are poorly understood in this carcinogenesis process, the terms promotion and progression have been used to describe the sum of the alterations.

Molecular biological markers of genomic instability in the lung include activated oncogenes (e.g., K-ras) and inactivated tumor suppressor genes (e.g., p53) as well as other molecular markers.

This project has partially supported modeling neoplastic transformation induced by exposure of cells to low- or high-LET radiations. The previously published NEOTRANS model $_{1}$ (Scott, 1997) for high-LET radiation-induced neoplastic transformation has now been used along with MCMC methods (Carlin and Lewis, 1996; Gamerman, 1997; Gilks et al., 1997; Miller and Inkret 1996a, b) to characterize the induction of neoplastically transformed cells (in vitro). The MCMC method is a powerful approach to integrating dosimetric, molecular, and cellular effects and has allowed us to discover what appears to be an ultrafast molecular process related to repair and misrepair of genomic damage. This process was first observed after evaluating data for high-LET neutron-induced neoplastic transformation (Scott, 1997). However, we now have evidence that ultrafast repair is associated with low-LET irradiation (Scott et al., 2000). The methods may also be powerful enough to allow inclusion of microdose distributions to the genomic target. However, we have not had success in incorporating microdose distributions as it causes already very long computer run times to be multiplied many fold.

With the NEOTRANS ${ }_{1}$ model, neoplastic transformation arises from radiation-induced, persistent problematic, genomic instability (PPI) that is passed from surviving irradiated parent cells to progeny cells. This instability in the genome is also considered to contribute to an increased risk of cancer for target cells in the lung. 
Based on these considerations, we have formulated the following two postulates that facilitate quantitative modeling of lung cancer risk associated with radiation exposure:

- Postulate 1: Genotoxic agents such as ionizing radiation produced PPI in surviving target cells that can be passed to cell progeny and lead to PPI among the progeny.

- Postulate 2: The lung cancer risk will be proportional to the number of surviving cells in the lungs that carry PPI.

Postulate 2 is consistent with most plausible mechanistic models of cancer induction (e.g., Armitage and Doll, 1954; Barrett and Wiseman, 1987; Bogen, 1989; Hoel et al., 1983;

Moolgavkar, 1983; Moolgavkar et al., 1990, 1993; Portier, 1987; Portier and Sherman, 1994; Portier et al., 1990; Tan, 1991; Thorslund et al., 1987; Whittemore and Keller, 1978).

Furthermore, for the stochastic-intake paradigm, one is dealing with a relatively small number of cells being irradiated by inhaled $\alpha \mathrm{E}$ particles for a very large number of cells at risk, and for very low probability events (i.e., tumor induction). Thus, for radiation exposure of the lung, liver, or skeleton from inhaled $\mathrm{Pu}$, the Poisson risk equation applies whereby:

$$
\text { Risk }=1-\exp \left(-h_{i}\right),
$$

where $i=L u, L i, S k$ for the lung, liver, and skeleton, respectively. Here, $h_{i}$ is the cumulative genomic hazard (i.e., a hazard function) for tumor induction. With the Poisson model, $h_{i}$, is proportional to the average number of cells in the lung with PPI. The averaging is over different individuals exposed to the same macroscopic absorbed radiation dose, rather than over cells in a single individual. With this model, the doubling dose for cancer induction equals the doubling dose for PPI.

\subsubsection{Joint Russian Federation/U.S. Case-control Study of Lung Cancer Induction by ${ }^{239} \mathrm{Pu}$}

Here we described results of a joint Russian Federation/U.S. effort related to studying lung cancer risks from inhaled ${ }^{239} \mathrm{Pu}$. This study was headed by Dr. Z. B. Tokarskaya of the First Institute of Biophysics (FIB-1), Ozersk Russia. Numerous staff at FIB-1 contributed to the study. Dr. Scott provided computation support for Monte Carlo evaluations related to uncertainty characterization and evaluation of the nature of interactions.

For radiation-related, cancer risk evaluation, it is very important to assess not only influences of individual risk factors but also their interactive effects (e.g. additive, multiplicative, etc.). We have used a multivariate analysis approach to investigate the pair-wise interactions of previously identified three main etiological factors for lung cancer induction in Russian workers of the Mayak Production Association (PA) nuclear enterprise. These three factors are as follows: (1) body burden of inhaled plutonium-239 $\left({ }^{239} \mathrm{Pu}\right)$, an influence on absorbed alpha radiation dose; (2) cumulative, absorbed external gamma radiation dose to the lung; and (3) level of cigarette smoking as indicated by a smoking index (SI). The SI represents the cigarettes smoked per day times years smoking.

Based on a cohort of 4,390 persons (77\% male), we conducted a nested, case-control study of lung cancer induction based on 486 matched cases and controls. Each case was matched to two controls. Matching was based on five factors: sex, year of birth, year work began, profession, and workplace. Standard statistical methods were used (Breslow and Day, 1980) based on discordant pairs.

Three levels of smoking were considered: low (SI = 1 to 499), used as a reference level; middle (SI = 500 to 900$)$; and high ( $\mathrm{SI}=901$ to 2000). Confidence intervals were generated for 
both additive and multiplicative odds ratios for individual factors based on the variable $\operatorname{Prob}=O R /(O R+1)$ having a normal distribution with the mean determined by the observed $\mathrm{OR}_{\mathrm{r}}$ associated with a given factor and variance according to the relationship $\operatorname{Prob}_{r}{ }^{*}\left(1-\operatorname{Prob}_{r}\right) / n$ where Prob $_{r}$ is Prob evaluated at the observed odds ratio $O R_{r}$, and $\mathrm{n}$ is the sum of discordant pairs of type I and type II. Monte Carlo evaluations of the distribution of $O R$ involved 10,000 realizations.

For lung cancer induction, a supra-multiplicative association was demonstrated for high external gamma ray dose (> $2.0 \mathrm{~Gy}$ ) plus high ${ }^{239} \mathrm{Pu}$ intake (body burden $>2.3 \mathrm{kBq}$ ). This observation is consistent with the hypothesis of a curvilinear dose-response relationship for lung cancer induction.

The interaction between radiation (external gamma rays or $\mathrm{Pu}-239$ body burden) and cigarette smoke was found to depend on the smoking level. For the middle level of smoking in combination with gamma radiation $(>2 \mathrm{~Gy})$ or $\mathrm{Pu}-239$ body burden $(>2.3 \mathrm{kBq})$, an additive effect could not be ruled out, even though a multiplicative effect was consistent with observations. However, for the high level of smoking in combination with gamma radiation (> 2Gy) or $\mathrm{Pu}-239$ body burden $(>2.3 \mathrm{kBq})$, multiplicative effects were demonstrated. These results indicate that risk estimates for radiation-induced lung cancer derived without adjusting for the influence of cigarette smoking could involve a large systematic error. Further, such error may considerably distort the shape of the risk vs. dose curve and could hide the presence of a dose threshold for radiation-induced lung cancer.

\section{Relevance, Impact, and Technology Transfer}

\subsection{Recommendations for Setting Radionuclide Soil Action Levels for Rocky Flats}

Our research results have direct application to $\mathrm{Pu}$-contamination issues related to the DOE Rocky Flats site. We provide on the web (http://www.radiation-scott.org/rockyflats/index.htm) a PowerPoint presentation that addresses the issues and provides advice related to dealing with the $\mathrm{Pu}$-contamination. A major issue is what are scientifically justifiable RSALs for Pu and other isotopes in soil at Rocky Flats. Key findings discussed in the poster related to setting RSALs for Rocky Flats soils are summarized below.

In setting final RSALs for the Rocky Flats site, all major uncertainties/variability must be addressed. Use of software such as RESRAD-Probabilistic may facilitate uncertainty/variability characterization. Key uncertainties/variability to be considered include the following:

- Uncertainty about future use of the site.

- Uncertainty in cancer risks for body organs/tissues where Pu isotopes concentrate (bone, bone surface, red bone marrow, lung, and liver).

- Uncertainty in dose conversion factors used to convert radioactivity intake to dose.

- Variability in the amount of Pu-contaminated soil inhaled by different individuals over years. This is predicted to be a major variability and therefore should not be disregarded.

Variability in respiratory tract geometry in a population of people is likely to contribute to variability in inhalation intake over years of airborne Pu. Some progress has been made in accounting for varying deposition in the respiratory tract due to varying respiratory tract geometries (Asgharian and Anjilvel, 1994; Balashazy and Hofmann, 1995; Heistracher et al., 
1995; Hofmann, 1996; Hofmann and Koblinger, 1990, 1992; Koblinger and Hofmann, 1985) and in varying transport rates after deposition (Koblinger and Hofmann, 1990).

\subsection{Implications of our Research for Worker Exposures at Rocky Flats to $\mathrm{Pu} / \mathrm{Am}$}

Our research results have important implications for worker protection at Rocky Flats and other DOE facilities where Pu-related work is carried out. Firstly, our research results indicate that for circumstances where relatively small numbers of highly radioactive $\mathrm{PuO}_{2}$ particles are airborne, a few workers could have relatively large intakes of $\mathrm{PuO}_{2}$ without a CAM alarm having occurred. In such cases, the workers may be unaware of their relatively large intakes but the intake occurrence could show up via a urine bioassay. Also, in other circumstances, a CAM alarm could occur with little or no worker intakes via inhalation of $\mathrm{PuO}_{2}$ by some, relatively large intakes by others, and no apparent intake by the remaining persons. This could happen even though the workers were in the same room, for about the same time and inhaled about the same amount of air. This type of exposure scenario is no longer theoretical as such an exposure occurred at Los Alamos in March of last year related to a glove-box release of ${ }^{238} \mathrm{PO}_{2}$.

\subsection{Implications of our Lung Cancer Risk Assessment Research}

Our research jointly conducted with scientists at the FIB-1, Ozersk, Russia has the following very important implications to evaluating lung cancer risks from inhaled $\mathrm{Pu}$ :

Cigarette smoking can influence the overall lung cancer risk in cases of combined exposure to radiation and smoke.

The nature of the interaction of radiation and cigarette smoke depends on both the levels of radiation exposure and cigarette smoking.

Radiation risk estimates for Pu-induced lung cancer in populations that include smokers may involve large systematic error if influences of smoking are not accounted for.

Not accounting for smoking influences on lung cancer risk could distort the shape or the radiation dose-response relationship, possibly masking the presence of a dose threshold.

\section{Project Productivity}

To date this project has accomplished most of its initial goals. Through a 1-year, no-cost extension of the project and through an approved renewal application, we expect that the remaining initial goals along with new goals associated with the renewed project will be completed within the remaining period for the renewed project.

Because of an unanticipated reduction in staff during the initial funding period, some project tasks were delayed, leading to requesting and being granted a 1-year no-cost extension.

Two key revisions were made in the work plan. Initially we had planned to derive new radioactivity-to-dose conversion factors for specific alpha-emitting radionuclides $\left({ }^{238} \mathrm{Pu},{ }^{239} \mathrm{Pu}\right.$, ${ }^{240} \mathrm{Pu},{ }^{241} \mathrm{Pu},{ }^{242} \mathrm{Pu},{ }^{244} \mathrm{Pu}$, and $\left.{ }^{241} \mathrm{Am}\right)$. Later it was decided to use dose conversion factors presently used internationally by the scientific community. Their use allows evaluation of upper bounds on cancer risk. We also had initially planned to investigate particle breakup effects on respiratory tract dosimetry for very high specific activity aerosols such of ${ }^{238} \mathrm{PuO}_{2}$. Alpha decay energy imparted to the ${ }^{238} \mathrm{PuO}_{2}$ matrix causes breakup and more rapid translocation from the lung. However, for real-world exposure scenarios related to Pu/Am at places like Rocky Flats,

${ }^{238} \mathrm{Pu}$ represents only a small portion of the radiation source radioactivity. For example, mixtures 
of ${ }^{238} \mathrm{Pu},{ }^{239} \mathrm{Pu},{ }^{240} \mathrm{Pu},{ }^{241} \mathrm{Pu},{ }^{242} \mathrm{Pu}$, and ${ }^{241} \mathrm{Am}$ in soil at Rocky Flats contain relatively small amounts of ${ }^{238} \mathrm{Pu}$. Thus, particle breakup research was de-emphasized.

Monthly project reports have been submitted to the DOE Albuquerque Operations Office (DOE/AL) on time for more than 3 years (except for one, which was delayed due to illness for the project PI). We received several compliments form DOE/AL for our rather detailed and informative reports.

Annual reports to EMSP have also been made on time. In addition, key research findings have been presented at scientific meetings, published in peer-reviewed journals, and are available on the web.

\section{Personnel Supported}

A large number of personnel have contributed to this project. They are listed below under categories of co-investigator, consultant, and technical support.

Co-investigators at LRRI (present and past): Dr. J. H. Diel, Dr. M. D. Hoover, Dr. M. Ménache, Dr. R. E. Neft, Dr. Y. Zhou, Dr. Y.-S. Cheng, and Mr. G. Newton

Co-investigators at FIB-1 in Ozersk Russia (via renewed project): Dr. N. D. Okladnikova,

Dr. Z. B. Tokarskaya, and Dr. G. V. Zhuntova,

Consultant in U.S. (via renewed project): Dr. S. S. Yaniv

Consultant in Russia (via renewed project): Dr. S. V. Osovets

Postdoctoral participant (2-year participation completed): Dr. H. Schöllnberger

Technical Support in U.S. (present and past): A. Fencl, B. Hines

Graduate Student (past participant): William Mulberry

\section{Publications}

Publications fully or partially supported by this EMSP project to date are listed below $[\mathrm{PR}=$ peer-reviewed; NPR $=$ not peer-reviewed $]$ :

Cheng, Y.-S., Y. Zhou, and B. T. Chen. "Particle deposition in a cast of human oral airways," Aerosol Sci. Technol. (in press).[PR]

Glissmeyer, J. A., J. L. Alvarez, B. C. Blunt, P. W. Frame, M. D. Hoover, A. P. Hull, J. M. Karhnak, A. R. McFarland, G. J. Newton, and J. C. Rodgers. American national standard for sampling and monitoring releases of airborne radioactive substances from the stacks and ducts of nuclear facilities, ANSI/HPS N13.1-1999, Health Physics Society, McLean, VA, 1999.[NPR]

Guilmette, R. A., and B. R. Scott. "Radiation toxicology," in Encyclopedia of Toxicology, Vol. 3, (P. Wexler, ed.), pp. 5-18, Academic Press, San Diego, 1998.[NPR]

Hoover, M. D., and G. J. Newton. "Performance testing of continuous air monitors for alphaemitting radionuclides," Radiat. Prot. Dosim. 79(1-4), 499-504, 1998.[PR]

Hoover, M. D., G. J. Newton, R. A. Guilmette, R. J. Howard, R. N. Ortiz, J. M. Thomas, S. M. Trotter, and E. Ansoborlo. "Characterization of enriched uranium dioxide particles from a uranium handling facility,” Radiat. Prot. Dosim. 79(1-4), 57-62, 1998.[PR] 
Hoover, M. D., C. J. Mewhinney, and G. J. Newton. "Modular glovebox connector and associated good practices for control of radioactive and chemically toxic materials," Health Phys. 76(1), 66-72, 1999.[PR]

Osovets, S. V., and B. R. Scott. "Nonmonotonous character of dose-response relationships." Viniti No. 1/4, 645, B98, March 6, 1998 (in Russian).[PR]

Scott, B. R. "Improved radiation dosimetry/risk estimates to facilitate environmental management of plutonium contaminated sites," in Environmental Management Science Program Workshop, U. S. Department of Energy Publication CONF-980736, Washington, DC, pp. 25-26, 1998. [NPR]

Scott, B. R., A. F. Lyzlov, and S. V. Osovets. "Evaluating the risk of death via the hematopoietic syndrome mode for prolonged exposure of nuclear workers to radiation delivered at very low rates." Health Phys. 74(5), 545-553, 1998.[PR]

Scott, B. R. “Transformation of C3H 10T1/2 cells," Letter to Editor, J. Radiol. Prot. 19(2), 177179, 1999. [NPR]

Scott, B. R., and A. Fencl. "Variability in $\mathrm{PuO}_{2}$ intake by inhalation: Implications for worker protection at the U. S. Department of Energy." Radiat. Prot. Dosim. 83(3), 221-232, 1999. [PR]

Scott, B. R. "Respiratory Tract," Chapter 5 in Biological Effects and Exposure Limits for "Hot Particles.” National Council on Radiation Protection and Measurements, Bethesda, MD. December 10, 1999. [PR]

Scott, B. R., and H. Schöllnberger (2000). "Introducing biological microdosimetry for ionizing radiation.” Radiat. Prot. Dosim. 91(4), 377-384. [PR]

Scott, B. R. (2001). An approach to evaluating intake distributions for inhaled plutonium dioxide for the stochastic intake paradigm. Health Phys. (submitted).

Schöllnberger, H., B. R. Scott, and T. E. Hanson (2001). Application of Bayesian inference to characterize risks associated with low doses of low-LET radiation. Bull. Math. Biol. (accepted for publication).

Tokarskaya, Z. B., V. F. Khokhryakov, G. V. Zhuntova, N. D. Okladnikova, Z. D. Belyaeva, B. R. Scott, and H. Schöllnberger (2001). Interaction of radiation and smoking in lung cancer induction among workers at the Mayak Nuclear Enterprise. Health Phys. (in revision).

\section{Interactions}

7.1 Presentations (Fully or Partially Supported by this EMSP Project) that Provided for Interactions with Other Researchers:

Cheng, Y.-S., H. C. Yeh, S. M. Smith, K. H. Cheng, and D. L. Swift. "Deposition of ultrafine particles in the nasal and tracheobronchial airways," 1998 International Aerosol Conference, Edinburgh, UK, Sept. 14-18, 1998.

Hoover, M. D., G. J. Newton, and F. M. Cox. "Sampling radioactive aerosols," American Academy of Health Physics Short Course, 31st Midyear Meeting of the Health Physics Society, Mobile, AL, February 7, 1998. 
Hoover, M. D. "Workplace air sampling methods and good practices," Technical Workshop on Air Sampling: The Big Picture, Savannah River Chapter, Health Physics Society, Aiken, SC, April 24, 1998.

Hoover, M. D. "Statistical considerations for aerosol sampling, professional enrichment short course," $43^{\text {rd }}$ Annual Meeting of the Health Physics Society, Minneapolis, MN, July 12, 1998.

Hoover, M. D., G. J. Newton, and F. M. Cox. "Flow measurements with rotameters and appropriate corrections," $43^{\text {rd }}$ Annual Meeting of the Health Physics Society, Minneapolis, MN, July 15, 1998.

Hoover, M. D. "Statistical considerations for aerosol sampling," Professional Enrichment Short Course, $32^{\text {nd }}$ Midyear Meeting of the Health Physics Society, Albuquerque, NM, January 24, 1999.

Osovets, S. V., and B. R. Scott. "Modeling of the dependence of median effective dose on dose Rate," 4th Conference on Radiation Investigation, Moscow, November 20-24, 2001. Abstract submitted (in Russian) for possible presentation of paper. English translation prepared by Dr. Shlomo Yaniv, March 2001 and will be available via the web.

Schöllnberger, H., D. J. Crawford-Brown, P. M. Eckl, M. R. Mebust, and W. Hofmann. "Radioprotective mechanisms and dose-response plateaus for initiation in a state-vector model of radiocarcinogenesis," poster presentation given at the $47^{\text {th }}$ Annual Meeting of Radiation Research Society, Albuquerque, NM, April 29-May 3, 2000.

Schöllnberger, H., B. R. Scott, and T. E. Hanson. "Application of Bayesian inference to characterize risks associated with low doses of low-LET radiation," presentation given at American Nuclear Society Trinity and Rio Grande Chapter Technical and Dinner Meeting, Crown Plaza Pyramid Hotel, Albuquerque, NM, October 27, 2000.

Scott, B. R., Y.-S. Cheng, J. H. Diel, M. D. Hoover, M. G. Ménache, R. E. Neft, G. J. Newton, M. B. Snipes, and Y. Zhou. "Evaluating the intake via inhalation of plutonium oxides for the stochastic exposure paradigm," Poster 13 presented at the Environmental Management Science Program Workshop, Chicago, IL, July 27-30, 1998.

Scott, B. R., M. D. Hoover, R. E. Neft, and A. Fencl. "Recommendations for improving the interim radionuclide soil action levels for the Rocky Flats Cleanup Agreement," poster presentation given at $218^{\text {th }}$ American Chemical Society National Meeting, New Orleans, LA, August 22-26, 1999.

Scott, B. R., Y. Tesfaigzi, and H. Schöllnberger. "Mechanistic models for radiation-induced neoplastic transformation," poster presentation given at $47^{\text {th }}$ Annual Meeting of Radiation Research Society, Albuquerque, NM, April 29-May 3, 2000.

Scott, B. R. "Radiological problems in the Chelyabinsk region of Russia," Special seminar at Beckman Institute, University of Illinois, sponsored by Russian and East European Center; Arms Control, Disarmament, and International Security Program; Department of Nuclear Plasma, and Radiological Engineering; Department of Molecular \& Integrative Physiology; Center for Biophysics and Computational Biology; Radiation Biophysics and Bioengineering in Oncology Training Program; October 24, 2000.

Scott, B. R. "Mechanistic models for radiation-induced neoplastic transformation: Bayesian approach to model characterization. Seminar at Beckman Institute, University of Illinois, 
sponsored by the Radiation Biophysics and Bioengineering in Oncology Training Program and the Center for Biophysics and Computational Biology; October 25, 2000.

Smith, S. M., Y. S. Cheng, and H. C. Yeh. "Diffusional deposition of ultrafine particles in human tracheobronchial airways," 1998 International Aerosol Conference, Edinburgh, UK, Sept. 14-18, 1998.

Zhang, Z., X. Wang, and Y.-S. Cheng. "Flow pattern and aerosol deposition in the human oral airway," 1998 International Aerosol Conference, Edinburgh, UK, Sept. 14-18, 1998.

7.2 Web Sites (Fully or Partially Supported by this EMSP Project) Presenting Key Information Related to Our Research:

Issues Related to Radionuclide Soil Action Levels for Rocky Flats (poster):

http://www.radiation-scott.org/rockyflats/index.htm

Improving Radionuclide Soil Action Levels for Rocky Flats (poster):

http://www.radiation-scott.org/rocky

Plutonium-Related Cases: http://www.radiation-scott.org/Cases.htm

Plutonium-Induced Health Effects, based on publications on Mayak workers:

http://www.radiation-scott.org/health.htm

Other Plutonium-Related Web Sites for scientific audiences; students:

http://www.radiation-scott.org/other.htm

Deposition of Radioactive Substances in the Respiratory Tract: http://www.radiationscott.org/deposition

Radiation Glossary for Students: http://www.lrri.org/radiation/rad.htm. Portrait presented of Dr. B. R. Scott sketched during air flight by Bela J. Kovach.

Electronic Borders' Dictionary of Health Physics: http://www.hpinfo.org

\section{Transitions:}

Through our EM-supported research, we have assisted the DOE Rocky Flats Environmental Technology Site in evaluating worker risks from inhaling large quantities of $\mathrm{Pu} / \mathrm{Am}$ for hypothetical accidents associated with D\&D operations. The DOE standards require evaluation at Rocky Flats of the consequences to the immediate worker from health effects other than cancer (e.g., deterministic effects) in order to know the intake level of Pu/Am (for specific mixtures) that corresponds to "serious injury" or "prompt death.." The isotopic mixtures of interest relate to weapon's grade $\mathrm{Pu}$ and include ${ }^{238} \mathrm{Pu},{ }^{239} \mathrm{Pu},{ }^{240} \mathrm{Pu},{ }^{241} \mathrm{Pu}$, and ${ }^{241} \mathrm{Am}$ in differing amounts. Because of our extensive research experience related to deterministic radiation effects from inhaled radionuclides, we were able to do the following:

- Convince Rocky Flats scientists that the current definition of "prompt death" was inappropriate for $\mathrm{Pu}$ and Am isotopes, so that the definition was modified to allow for delayed non-cancer deaths that may occur several years after inhalation intake of such radionuclides. The delayed deaths relate to the late-occurring deterministic effects (e.g., pulmonary fibrosis, radiation pneumonitis) of irradiation. Such deaths can arise up to 5 years after inhaling large quantities of alpha-emitting radionuclides. 
- Introduce Rocky Flats scientists to a computational approach developed by Dr. B. R. Scott for evaluating risk for deterministic effects for the complex dose-rate patterns that arise from inhaling mixtures of Pu isotopes and americium (Scott et al., 1989). The computational approach is considered more reliable than the approaches presently used in the MACCS and COSEMY computer codes (NRC, 1997), which apply to nuclear accident risk assessment.

- $\quad$ Provide a Monte Carlo-based scheme to Rocky Flats scientists for including uncertainty/variability in their risk calculations.

- Persuade Rocky Flats scientists to abandon the inappropriate use of committed effective dose equivalent when dealing with deterministic effects of irradiation. We pointed out the huge systematic error that could arise from such usage.

Results of the Rocky Flats/LRRI collaborations indicate that mg quantities of Pu/Am need to be inhaled in order for the risk of death to be significant from deterministic effects in the lung or for serious respiratory dysfunction. Since both death from deterministic effects in the lung and serious morbidity from lung injury occurred in Mayak facility workers in Russia who were involved in Pu production work, we conclude that those workers likely inhaled mg quantities of ${ }^{239} \mathrm{Pu} /{ }^{241} \mathrm{Am}$.

As a result of this collaboration, a paper was written by Dr. Vern Peterson of Rocky Flats has written a paper, and the information will be presented at a June 17-21, 2001, conference in Milwaukee (Energy Facility Contractors Group/Safety Analysis Working Group Conference). The paper is entitled "Deterministic Health Effects from Plutonium Inhalation."

\section{Patents}

No patents were associated with our research.

\section{Future Work}

Our future work (largely related to a renewed application) will mainly focus on the following tasks:

- Continue joint U.S./Russian Federation research related to Pu/Am-induced cancer in Mayak workers.

- $\quad$ Develop a biological dosimetry system for Pu intake by Mayak workers.

- Conduct respirator-penetration studies for Pu aerosols.

- Continue to educate DOE staff about the implications of our research for worker and public protection from radiation-associated harm.

- Continue to educate the public via the web about ionizing radiation and its biological effects.

This work will benefit from our DOE/Science project that deals with understanding mechanisms associated with low-dose radiation-induced stochastic effects. 


\section{Literature Cited}

Altman, J. L., D. A. Cirrincione, N. L. Erdamm. N. L. Stallcup, and D. R. Stanton (1992). Rocky Flats Plant Site Environmental Report for 1991. Report RFP-ENV-91, EG\&G Rocky Flats, Rocky Flats Plant, Golden, CO.

Armitage, P., and R. Doll (1954). The age distribution of cancer and a multistage theory of cancer. Br. J. Cancer 8, 1-12.

Asgharian, B., and S. Anjilvel (1994). A Monte Carlo calculation of the deposition efficiency of inhaled particles in lower airways. J. Aerosol. Sci. 25(4), 711-721.

Balashazy, I., and W. Hofmann (1995). Deposition of aerosols in asymmetric airway bifurcations. J. Aerosol. Sci. 26(2), 273-292.

Barrett, J. C., and R. Wiseman (1987). Cellular and molecular mechanisms of multistep carcinogenesis: Relevance to carcinogen risk assessment. Environ. Health Perspect. 76, $65-70$.

Bettega., D., P. Calzolari, A. Ottolenghi, and L. Tallone Lombardi (1990). Oncogenic transformation induced by high and low LET radiations. Radiat. Prot. Dosim. 31(1/4), 279-283.

Bettega, D., P. Calzolari, G. N. Chiorda, and L. Tallone-Lombardi (1992). Transformation of C3H 10T1/2 cells with $4.3 \mathrm{MeV}$ alpha particles at low doses: Effects of single and fractionated doses. Radiat. Res. 131(1), 66-71.

Bogen, K. (1989). Cell proliferation kinetics and multistage cancer risk models. J. Natl. Cancer Inst. 81, 267-277.

Breslow, N. E., and N. E. Day (1980). The analysis of case-control studies. In Statistical Methods in Cancer Research (W. Davis, ed.), Vol. 1, International Agency for Research on Cancer, Lyon.

Carlin, B. P. and R. A. Louis (1996). Bayes and Empirical Bayes Methods for Data Analysis. Chapman \& Hall, London.

CDH (1990). Rocky Flats Surface Soil Survey 1970-1989. Radiation Control Division, Colorado Department of Health, Denver, CO.

Decisioneering (1996). Crystal Ball Users Manual, Version 4.0. Decisioneering, Inc., Denver, $\mathrm{CO}$.

Diel, J. H., and J. A. Mewhinney (1983). Fragmentation of inhaled ${ }^{238} \mathrm{PuO}_{2}$ particles in the lung. Health Phys. 44, 135-143.

DOE/EPA/CDPHE (1996). Action Levels for Radionuclide in Soils for the Rocky Flats Cleanup Agreement. Final. U. S. Department of Energy, U. S. Environmental Protection Agency, Colorado Department of Public Health and the Environment, October 31, 1996.

Gamerman, D. (1997). Markov Chain Monte Carlo. Chapman \& Hall, London.

Gilbert, E. S., N. A. Koshurnikova, M. Sokolnikov, V. G. Khokhryakov, S. Miller, D. L. Preston, S. A. Romanov, N. S. Shilnikova, K. G. Suslova, and V.V. Vostroitin (2000). Liver cancers in Mayak workers. Radiat. Res. 154, 242-252. 
Gilks, W. R., S. Richardson, and D. J. Spieglehalter (Eds.) (1997). Markov Chain Monte Carlo. Chapman \& Hall, London.

Heistracher, T., I. Balashazy, and W. Hofmann (1995). The significance of secondary flows for localized particle deposition in bronchial airway bifurcations. J. Aerosol. Sci. 26(Suppl I), S615-S616.

Hickman, A. W., W. C. Griffith, G. S. Roessler, and R. A. Guilmette (1995). Application of a canine ${ }^{238} \mathrm{Pu}$ biokinetics/dosimetry model to human bioassay data. Health Phys. 68, 359370 .

Hoel, D., N. Kaplan, and M. Anderson (1983). Implication of nonlinear kinetics on risk estimation in carcinogenesis. Science 219, 1032-1037.

Hofmann, W. (1996). Modeling techniques for inhaled particle deposition: The state of the art. J. Aerosol Med. 9(3), 369-388.

Hofmann, W., and L. Koblinger (1990). Monte Carlo modeling of aerosol deposition in human lungs. Part II: Deposition fractions and their sensitivity to parameter variations. J. Aerosol. Sci. 21(5), 675-688.

Hofmann, W., and L. Koblinger (1992). Monte Carlo modeling of aerosol deposition in human lungs. Part III: Comparison with experimental data. J. Aerosol. Sci. 23(1), 51-63.

Hoover, M. D., and G. J. Newton (1993). Calibration and operation of continuous air monitors for alpha-emitting radionuclides. In Proceedings of the Radiation Protection Workshop, U. S. Department of Energy Publication CONF-93-04128, pp. G-27-G-38.

ICRP (1979). Limits for Intakes of Radionuclides by Workers. ICRP Publication 30, International Commission on Radiological Protection, Pergamon, Oxford.

ICRP (1994). Human Respiratory Tract Model for Radiological Protection. ICRP Publication 66, International Commission on Radiological Protection, Pergamon, Oxford, Ann. ICRP 24 No. 1-4.

Jones, R. H. and Y. Zhang (1994). Spatial and Temporal Analysis of the Rocky Flats Soil Plutonium Data. Colorado Department of Public Health and Environment, Denver, CO.

Koblinger, L., and W. Hofmann (1985). Analysis of human lung morphometric data for stochastic deposition calculations. Phys. Med. Biol. 30(6), 541-556.

Koblinger, L. and W. Hofmann (1990). Monte Carlo modeling of aerosol deposition in human lungs. Part I: Simulation of particle transport in a stochastic lung structure. J. Aerosol. Sci. 21, 661-647.

Koshurnikova, N. A., E. S. Gilbert, M. Sokolnikov, V. F. Khokhryakov, S. Miller, D. L. Preston, S. A. Romanov, N. S. Shilnikova, K. G. Suslova, and V. V. Vostrotin (2000). Bone cancers in Mayak workers. Radiat. Res. 154, 237-245.

Kotrappa, P., C. J. Wilkinson, and H. A. Boyd (1972). Technology for the production of monodisperse aerosols of oxides of transuranic elements for inhalation experiments. Health Phys. 22, 837-843.

Kreisheimer, M. N., N. A. Koshurnikova, E. Nelolla, V. F. Khokhryakov, S. A. Romanov, M. E. Sokolnikov, N. S. Shilnikova, P. V. Okatenko, and A. M. Kellerer (2000). Lung cancer 
mortality among male nuclear workers of the Mayak facilities in the former Soviet Union. Radiat. Res. 154, 3-11.

Krey, P. W. and E. P. Hardy (1970 or 1976? page 2). Plutonium in Soil Around the Rocky Flats Plants. Report HASL-232, Health and Safety Laboratory, U. S. Atomic Energy Commission, New York.

Lechner, J. H., and J. L. Mauderly (1994). Sequence of events in lung carcinogenesis: Initiation and promotion, protooncogenes and tumor suppresser genes, and particles. In Toxic and Carcinogenic Effects of Solid Particles in the Respiratory Tract (U. Mohr, D. L. Dungworth, J. L. Mauderly, and G. Oberdörster, eds.), pp. 236-251, International Life Sciences Institute (ILSI) Press, Washington, DC.

Mewhinney, J. A., and J. H. Diel (1983). Retention of inhaled ${ }^{238} \mathrm{PuO}_{2}$ in beagles: A mechanistic approach to description. Health Phys. 45, 36-60.

Miller, G. and W. C. Inkret (1996a). Bayesian methods for interpreting plutonium urinalysis data. In Maximum Entropy and Bayesian Methods, pp. 367-373, Kluwer Academic Publishers, Boston.

Miller, G. and W. C. Inkret (1996b). Bayesian maximum posterior probability method for interpreting plutonium urinalysis data. Radiat. Prot. Dosim. 63, 189-196.

Moolgavkar, S. H. (1983). Model for human carcinogenesis: Action of environmental agents. Environ. Health Perspect. 50, 285-291.

Moolgavkar, S. H., F. T. Cross, G. Luebeck, and G. E. Dagle (1990). A two-mutation model for radon-induced lung tumors in rats. Radiat. Res. 121, 28-37.

Moolgavkar, S. H., E. G. Luebeck, D. Krewski, and J. M. Zielinski (1993). Radon, cigarette smoke, and lung cancer: A reanalysis of the Colorado plateau uranium miners' data. Epidemiology 4(3), 204-217.

NCRP (1996). Screening Models for Releases of Radionuclides to Atmosphere, Surface Water, and Ground-Work Sheets. NCRP Report No. 123, National Council on Radiation Protection and Measurement, Bethesda, MD.

NCRP (1999). Recommended Screening Limits for Contaminated Surface Soil and Review of Factors Relevant to Site-Specific Studies. NCRP Report No. 129, National Council on Radiation Protection and Measurement, Bethesda, MD.

Newton, G. J., R. A. Guilmette, F. A. Seiler, L. S. Quindos, and H. C. Yeh (1986). Evaluation of an X-ray based continuous monitor for airborne plutonium for use in the Waste Isolation Pilot Plant (WIPP). In Aerosols: Formation and Reactivity, pp. 1126-1129, Pergamon Press.

Newton, G. J., M. D. Hoover, E. B. Barr, B. A. Wong, and P. D. Ritter (1987). Collection and characterization of aerosols from metal cutting techniques typically used in decommissioning nuclear facilities. Am. Ind. Hyg. Assoc. J. 48, 922-932.

\section{NRC, 1997}

Okladnikova, N., and L. Burak (1993). Late cytogenetic effects of chronic professional radiation. Bull. Radiat. Med. 1, 85-90. 
Okladnikova, N. D., V. Pesternikova, and M. Sumina (1992a). The consequences of professional radiation. Nauchniy Informacionno Metodichesciy Byulleten, Lenigrad 4, 15 16.

Okladnikova, N. D., V. Pesternikova, M. Sumina, N. Kabasheva, and T. Azizova (1992b). Chronic radiation sickness of humans induced by external gamma-radiation, late period. Vestnik of Medical Scientifices Academy 2, 22-24.

Okladnikova, N. D., V. Pesternikova, M. Sumina, and V. Doshenko (1993). Occupational disease of radiation at first plant of atomic industry. Med. Radiologiya 38(12), 24-28.

Okladnikova, N., D. Z. Tokarskaya, and O. Musatkova (1994a). Cytogenetic effect of Pu-239 incorporation and external gamma-radiation (clinical investigation). Med. Radiologiya $39(5), 48-52$.

Okladnikova, N. D., V. Pesternikova, M. Sumina, and V. Doshenko (1994b). Occupational diseases from radiation exposure at the first nuclear plant in the USSR. Sci. Total Environ. 142, 9-17.

Portier, C. J. (1987). Statistical properties of a two-stage model of carcinogenesis. Environ. Health Perspect. 76, 125-131.

Portier, C. J., and C. D. Sherman (1994). Potential effects of chemical mixtures on the carcinogenic process within the context of the mathematical multistage model. In Toxicology of Chemical Mixtures, Case Studies, Mechanisms, and Novel Approaches (R. S. H. Yang, ed.), pp. 665-686, Academic Press, San Diego.

Portier, C. J., D. G. Hoel, N. L. Kalpan, and A. Kopp (1990), Biologically based models for risk assessment. In Complex Mixtures and Cancer Risk (H. Vainio, M. Sorsa, and A. J. McMichael, eds.), pp. 20-28, International Agency for Research on Cancer, Lyon.

Raabe, O. G. (1994). Characterization of radioactive airborne particles. Chapter 7 in Internal Radiation Dosimetry, Health Physics Society 1994, Summer School, (O. G. Raabe, ed.), pp. 111-142, Medical Physics Publishing, Madison, WI.

RSALOP (1999a). Task 1: Cleanup Levels at Other Sites. Radionuclide Soil Action Level Oversight Panel, Report draft (April 1999) submitted to the RSALOP by Risk Assessment Corporation.

RSALOP (1999b). Task: 2: Computational Models. Radionuclide Soil Action Level Oversight Panel, Report draft (July 1999) submitted to the Radionuclide Soil Action Level Panel by Risk Assessment Corporation.

RSALOP (1999c). Task 3: Independent Calculations. Radionuclide Soil Action Level Oversight Panel, Report draft (October 1999) submitted to the Radionuclide Soil Action Level Panel by Risk Assessment Corporation.

RSALOP (1999d). Task 5: Independent Calculations. Radionuclide Soil Action Level Oversight Panel, Report draft (November 1999) submitted to the Radionuclide Soil Action Level Panel by Risk Assessment Corporation.

Scott, B. R. (1995). A generic model for estimating the risk of deterministic effects of partial organ irradiation by hot particles. Health Phys. 69, 909-916. 
Scott, B. R. (1997). A mechanistic model for neoplastic transformation of cells by high-LET radiation and its implications for low-dose, low-dose-rate, risk assessment. Radiat. Prot. Dosim. 72(2), 105-117.

Scott., B. R., and A. Fencl (1999). Variability in $\mathrm{PuO}_{2}$ intake by inhalation: Implications for worker protection at the U.S. Department of Energy. Radiat. Prot. Dosim. 83(3), 221-232.

Scott, B. R., R. E. Filipy, and F. F. Hahn (1989). Models for Pulmonary Lethality and Morbidity After Irradiation From Internal and External Sources. Report NUREG/CR-5351, U. S. Nuclear Regulatory Commission, Washington, DC.

Scott, B. R., F. F. Hahn, M. B. Snipes, G. J. Newton, A. F. Eidson, J. L. Mauderly, and B. B. Boecker (1990). Predicted and observed early effects of combined alpha and beta lung irradiation. Health Phys. 59, 791-805.

Scott, B. R., E. S. Gilbert, and B. B. Boecker (1993). Late somatic effects. Chapter 3 in Health Effects Models for Nuclear Power Plant Accident Consequence Analysis, Modification of Models Resulting from Addition of Effects of Exposure to Alpha-Emitting Radionuclides, Part II. Scientific Basis for Health Effects Models, Nuclear Regulatory Commission Report NUREG/CR-4214, Rev. 1, Part II, Addendum 2, pp. 29-52.

Scott, B. R., M. D. Hoover, and G. J. Newton (1997). On evaluating respiratory tract intake of high-specific-activity alpha-emitting particles for brief occupational exposure. Radiat. Prot. Dosim. 69, 43-50.

Scott, B. R., M. D. Hoover, R. E. Neft, and A. Fencl (1999). Recommendations for improving the interim radionuclide soil action levels for the Rocky Flats Cleanup Agreement. Poster presentation given at the $218^{\text {th }}$ American Chemical Society National Meeting, New Orleans, LA, August 22-26, 1999.

Scott, B. R., Y. Tesfaigzi, and H. Schöllnberger (2000). Mechanistic models for radiationinduced neoplastic transformation. Presented at the 47th Annual Meeting of Radiation Research Society, Albuquerque, NM, April 29-May 3, 2000.

Scott, B. R., and H. Schöllnberger (2000). Introducing biological microdosimetry for ionizing radiation. Radiat. Prot. Dosim. 91(4), 377-384.

Tan, W. Y. (1991). Stochastic Models of Carcinogenesis. Marcel Dekker, Inc., New York.

Thorslund, T., C. Brown, and G. Charnley (1987). Biologically motivated cancer risk models. Risk Anal. 7, 109-119.

Tokarskaya, Z. B., and G. D. Basogolov (1995). The functional state of liver for the persons, contacted with aerosols of ${ }^{239} \mathrm{Pu}$ and external gamma-irradiation. Radiatiya i Risk 5, 9195.

Tokarskaya, Z. B., and V. F. Khokhryakov (1975). Aminotransferases of serum for workers at a radiochemical enterprise. Byulleten Radiacionnoy Mediciny 1, 5-122.

Tokarskaya, Z. B., N. D. Okladnikova, Z. B. Belyaeva, and E. G. Drozhko (1995). The influence of radiation and non-radiation factors on lung cancer incidences among the workers of the nuclear enterprise "Mayak." Health Phys. 69, 456-466.

US DOE (1996). The 1996 Baseline Environmental Management Report. Office of Environmental Management Report DOE/EM-0290, U. S. Department of Energy, Washington, DC. 
USNRC (1997). Probabilistic Accident Consequence Uncertainty Analysis, Early Health Effects Uncertainty Assessment, U. S. Nuclear Regulatory Commission Report NUREG/CR-6545, Vol. 2, U. S. Nuclear Regulatory Commission, Washington, DC 20555-0001.

Whittemore, A., and J. Keller (1978). Quantitative theories of carcinogenesis. SIAM Rev. 20, $1-30$. 